\title{
Fentanyl but not Morphine Interacts with Nonopioid Recombinant Human Neurotransmitter Receptors and Transporters
}

\author{
Randy Torralva, Amy J. Eshleman, Tracy L. Swanson, Jennifer L. Schmachtenberg, \\ William E. Schutzer, Shelley H. Bloom, Katherine M. Wolfrum, John F. Reed, \\ and Aaron Janowsky
}

Research Service, VA Portland Health Care System, Portland, Oregon (R.T., A.J.E., T.L.S., J.L.S., W.E.S., S.H.B., K.M.W., J.F.R., A.J.); Coda Research, Portland, Oregon (R.T.); Departments of Psychiatry (R.T., A.J.E., T.L.S., J.L.S., W.E.S., S.H.B., K.M.W., J.F.R., A.J.), Behavioral Neuroscience (A.J.E., A.J.), Oregon Health \& Science University, Portland, Oregon; and The Methamphetamine Abuse Research Center, VA Portland Health Care System and Oregon Health \& Science University, Portland, Oregon (W.E.S., A.J.)

Received February 4, 2020; accepted June 1, 2020

\section{ABSTRACT}

Synthetic opioids, including fentanyl and its analogs, have therapeutic efficacy in analgesia and anesthesia. However, their illicit use in the United States has increased and contributed to the number one cause of death for adults 18-50 years old. Fentanyl and the heroin metabolite morphine induce respiratory depression that can be treated with the $\mu$ opioid receptor (MOR) antagonist naloxone. With higher or more rapid dosing, fentanyl, more than morphine, causes chest wall rigidity and can also induce rapid onset laryngospasm. Because non-MORs could mediate differing clinical manifestations, we examined the interactions of fentanyl and morphine at recombinant human neurotransmitter transporters, G protein-coupled receptors, and the N-methyl-Daspartate glutamate receptor. Both drugs were agonists at MOR, $\kappa$, and $\delta$ opioid receptors. Morphine had little or no affinity at other human receptors and transporters $\left(K_{\mathrm{i}}\right.$ or $\mathrm{IC}_{50}$ value $>100$ $\mu \mathrm{M})$. However, fentanyl had $K_{\mathrm{i}}$ values of 1407 and $1100 \mathrm{nM}$ at $\alpha_{1 \mathrm{~A}}$ and $\alpha_{1 \mathrm{~B}}$ adrenoceptor subtypes, respectively, and $K_{\mathrm{i}}$ values of 1049 and $1670 \mathrm{nM}$ at dopamine D4.4 and D1 receptor subtypes, respectively; it also blocked $\left[{ }^{3} \mathrm{H}\right]$ neurotransmitter uptake by the vesicular monoamine transporter $2\left(\mathrm{IC}_{50}=911 \mathrm{nM}\right)$. Pharmacokinetic models indicate that these $\mathrm{Ki}$ and $\mathrm{IC}_{50}$ values are pharmacologically relevant. Fentanyl had little affinity for other receptors or transporters. Thus, noradrenergic disposition at specific receptor subtypes in relevant organs may play a role in respiratory and cardiothoracic effects of fentanyl. Data suggest that less selective fentanyl receptor pharmacology could play a role in the different clinical effects of morphine compared with fentanyl, including fentanyl-induced deaths after illicit use.

\section{SIGNIFICANCE STATEMENT}

The synthetic opioid fentanyl induces different clinical effects, including rapid onset muscular rigidity, vocal cord closure, and rapid death, than the heroin metabolite morphine. Our data indicate for the first time that the two drugs have very different effects at recombinant human neurotransmitter receptors and transporters that might explain those clinical differences.

\section{Introduction}

Fentanyl (N-phenyl-N-[1-(2-phenylethyl)-4-piperidinyl] propanamide), a synthetic opioid, and its analogs (F/FAs) are involved in almost twice as many opioid-induced deaths as heroin (diacetyl morphine), the metabolic precursor of morphine ((Hedegaard et al., 2018); Jannetto et al., 2019). However, in hospitals, fentanyl use for analgesia and anesthesia is routine (Stanley, 2014). Side effects include respiratory depression that is treated with naloxone, a $\mu$ opioid receptor (MOR) antagonist. Additionally, fentanyl-induced severe skeletal muscle rigidity

Funding for this study was provided by the United States Department of Justice, Drug Enforcement Administration [Grant D-15-OD-0002], Department of Veterans Affairs Merit Review [Grant I01BX002758] and Career Scientist programs [Grant 14S-RCS-006], National Institutes of Health National Institute on Drug Abuse Methamphetamine Abuse Research Center [Grant P50DA018165], and National Institutes of Health National Institute on Drug Abuse interagency agreement [Grant ADA12013]. The contents do not represent the views of the U.S. Department of Veterans Affairs, U.S. Department of Justice, Drug Enforcement Administration, or the United States Government.

All authors declare that they have no conflicts of interest.

https://doi.org/10.1124/jpet.120.265561.
(FIMR) of the chest wall and diaphragm and acute vocal cord closure (laryngospasm) require a muscle relaxant/paralytic and endotracheal intubation to restore adequate ventilation. These fentanyl-induced respiratory effects (FIRE) may play a role in rapid death associated with illicit fentanyl use.

Symptoms of overdose from illicit use of heroin similarly include naloxone-reversible respiratory depression. However, patients who overdose after illicit fentanyl exposure are far less likely to recover even after treatment with naloxone (Slavova et al., 2017), and higher doses of naloxone are generally required (Somerville et al., 2017). This reduced sensitivity to naloxone could be because of non-MOR-related effects of fentanyl and may explain why deaths from F/FAs continue to increase (Baumann et al., 2018). In fact, naloxone in higher doses causes noncardiogenic pulmonary edema (Jiwa et al., 2018), exacerbating respiratory failure and non-MOR-mediated symptoms of opioid overdose. Rapidity of injection and dose of fentanyl are the key determinants of the incidence, severity, and duration of FIRE (Grell et al., 1970). Symptoms occur within 2 minutes of drug injection and 


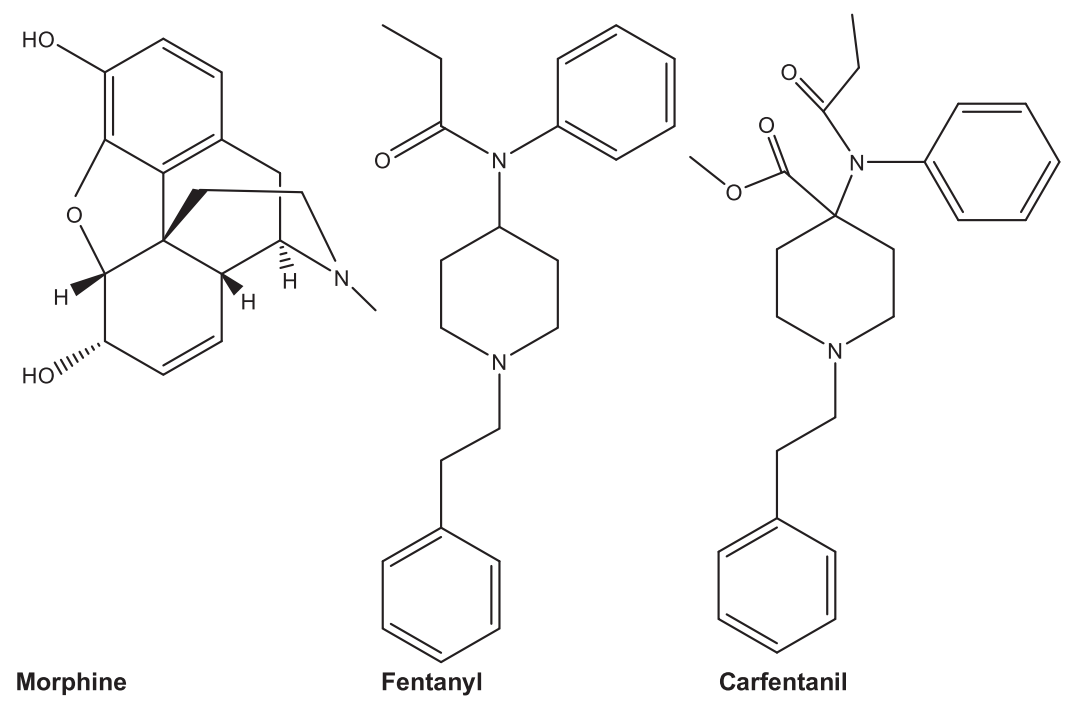

Fig. 1. Structures of morphine, fentanyl, and carfentanil.

can last up to 15 minutes (Scamman, 1983; Streisand et al., 1993). Fentanyl's inactive metabolite, norfentanyl, appears in plasma within 90 seconds of a bolus intravenous injection (McClain and Hug, 1980), but little norfentanyl is found in autopsy tissue from overdose deaths because of fentanyl (Burns et al., 2016). The absence of metabolite suggests that death from a bolus injection of fentanyl is rapid, distinguishing it from respiratory depression after heroin overdose.

Complex fentanyl pharmacokinetics vary across compartments (plasma, cerebrospinal fluid, brain lipid) (Peng and Sandler, 1999). Although fentanyl plasma concentrations are much lower than brain lipid concentrations (Chesser et al., 2019), the high lipid solubility and rapidity of exposure to the CNS after high-dose fentanyl suggests that micromolar $K_{\mathrm{i}}$ values for fentanyl binding to non-MORs could be relevant under toxic conditions (Stone and DiFazio, 1988; Yamanoue et al., 1993; Hustveit, 1994).

Descriptions of nonopioid receptor pharmacology, i.e., direct interaction between morphine or fentanyl and human signal transduction proteins, which could be linked to the disparate clinical effects of fentanyl and morphine, are sparse (see NIMH Psychoactive Drug Screening Program database: https://pdsp.unc.edu/databases/pdsp.php). Locus coeruleus (LC) activation may play a role in FIMR and FIRE, and multiple animal studies suggest that fentanyl interacts with

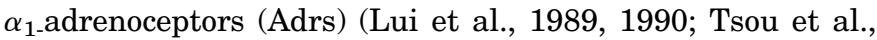
1989; Fu et al., 1997). Additionally fentanyl interacts with the human dopamine transporter in vivo (Bergström et al., 1998) and fentanyl displaces $\left[{ }^{3} \mathrm{H}\right] 8$-hydroxy-2-(di-n-propylamino) tetralin (8-OH-DPAT) from serotonin (5-HT) 1A receptors in rat brain preparations (Martin et al., 1991) and transfected cells (Rickli et al., 2018). Finally, fentanyl interacts with the human ether a-go-go-related gene potassium channel, but morphine does not (Katchman et al., 2002; Tschirhart et al., 2019), which could play a role in fentanyl-mediated rapid changes in cardiovascular function.

Data described herein are the first to show that morphine has low affinity $\left(K_{\mathrm{i}} \sim 100 \mu \mathrm{M}\right)$ at the examined recombinant human nonopioid receptors and transporters, whereas fentanyl has high nanomolar or low micromolar $K_{\mathrm{i}}$ or $\mathrm{IC}_{50}$ values for displacing radioligand binding or antagonizing function at specific recombinant human $\alpha_{1}$-Adr subtypes, the vesicular monoamine transporter (VMAT2), and the dopamine D1 and D4.4 receptor subtypes. Furthermore, carfentanil, a potent fentanyl analog, had binding affinities similar to fentanyl for $\alpha_{1}$-Adr subtypes. Conversely, $K_{\mathrm{i}}$ values for fentanyl at displacing radioligand binding at serotonin $1 \mathrm{~A}$, 2A, 2B, and 2C; dopamine D2 and D3; cannabinoid CB1; and $\mathrm{N}$-methyl-D-aspartate (NMDA) G2a/G1 receptors as well as at dopamine (DAT), norepinephrine (NET), and serotonin (SERT) transporters were in the high micromolar range. Additionally, we investigated the effects of fentanyl on receptor and transporter function where fentanyl binding affinity was pharmacologically relevant, and the data indicate that fentanyl is an inhibitor/antagonist of function. These data suggest that there are significant differences between morphine and fentanyl pharmacology. This, along with previously published results indicating that the effects

ABBREVIATIONS: Adr, adrenoceptor; BSA, bovine serum albumin; $\mathrm{CHO}$, Chinese hamster ovary cells; CNS, central nervous system; DAMGO, [D$\mathrm{Ala}^{2} ; \mathrm{N}$-MePhe ${ }^{4}$, Gly-ol]-enkephalin; DAT, dopamine transporter; DHTB, dihydrotetrabenazine; DMEM, Dulbecco's modified Eagle's medium; DPDPE, [D-Pen ${ }^{2}$,D-Pen ${ }^{5}$ encephalin; DOR, human $\delta$ opioid receptor; F/FA, fentanyl and fentanyl analogues; FIMR, fentanyl-induced muscular rigidity; FIRE, fentanyl-induced respiratory effects; GTPyS, guanosine 5'-O-[gamma-thio]triphosphate; 5-HT, serotonin; IP-1, inositol-1 phosphate; $\mathrm{HEK}$, human embryonic kidney cells; $\mathrm{K}_{\mathrm{D}}$, Dissociatoin constant; KOR, human $\kappa$ opioid receptor; LC, locus coeruleus; MK-801 (dizocilpine), (5S,10R)(+)-5-methyl-10,11-dihydro-5H-dibenzo[a,d]cyclohepten-5,10-imine maleate; MOR, $\mu$ opioid receptor; NE, norepinephrine; NET, norepinephrine transporter; NMDA, N-methyl-D-aspartate; 8-OH-DPAT, 8-hydroxy-2-(di-n-propylamino) tetralin; PI, protease inhibitors; RTI-55, methyl (1R,2S,3S)3-(4-iodophenyl)-8-methyl-8-azabicyclo[3.2.1]octane-2-carboxylate; SCH23390, 7-chloro-3-methyl-1-phenyl-1,2,4,5-tetrahydro-3-benzazepin-8ol; SERT, serotonin transporter; SKF38393, ( \pm )-1-Phenyl-2,3,4,5-tetrahydro-(1H)-3-benzazepine-7,8-diol; TME buffer 20 mM Tris, 5 mM MgCl2, $1 \mathrm{mM}$ EDTA, pH 7.4 at $4^{\circ} \mathrm{C}$ U69,593, (+)-(5 $\left.\alpha, 7 \alpha, 8 \beta\right)$-N-Methyl-N-[7-(1-pyrrolidinyl)-1-oxaspiro[4.5]dec-8-yl]-benzeneacetamide; VMAT2, vesicular monoamine transporter 2. 
TABLE 1

Fentanyl and morphine interactions with opioid receptor subtypes

Experiments were conducted as described in the text.

\begin{tabular}{|c|c|c|c|}
\hline Drug & $\begin{array}{c}\text { CHO-rMOR }\left[{ }^{3} \mathrm{H}\right] \text { DAMGO Binding } \\
K_{\mathrm{i}}(\mathrm{nM}) \pm \text { S.E.M. }(n) \\
\text { Hill Slope } \pm \text { S.E.M. }\end{array}$ & $\begin{array}{c}\text { CHO-hKOR }\left[{ }^{3} \mathrm{H}\right] \mathrm{U} 69,593 \text { Binding } \\
K_{\mathrm{i}}(\mathrm{nM}) \pm \text { S.E.M. }(n) \\
\text { Hill Slope } \pm \text { S.E.M. }\end{array}$ & $\begin{array}{c}\text { CHO-hDOR }\left[{ }^{3} \text { H]DPDPE Binding }\right. \\
K_{\mathrm{i}}(\mathrm{nM}) \pm \text { S.E.M. }(n) \\
\text { Hill Slope } \pm \text { S.E.M. }\end{array}$ \\
\hline \multirow[t]{2}{*}{ Fentanyl } & $0.35 \pm 0.05(16)$ & $125 \pm 15(14)$ & $244 \pm 20(12)$ \\
\hline & $-0.78 \pm 0.05$ & $-0.95 \pm 0.05$ & $-1.07 \pm 0.04$ \\
\hline \multirow[t]{5}{*}{ Morphine } & $0.58 \pm 0.8(19)$ & $27 \pm 3(15)$ & $178 \pm 14(12)$ \\
\hline & $-0.97 \pm 0.05$ & $-0.98 \pm 0.04$ & $-1.06 \pm 0.04$ \\
\hline & {$\left[{ }^{35} \mathrm{~S}\right] \mathrm{GTP} \gamma \mathrm{S}$ Binding } & {$\left[{ }^{35} \mathrm{~S}\right] \mathrm{GTP} \gamma \mathrm{S}$ Binding } & {$\left[{ }^{35} \mathrm{~S}\right] \mathrm{GTP} \gamma \mathrm{S}$ Binding } \\
\hline & $\mathrm{EC}_{50}(\mathrm{nM}) \pm$ S.E.M. $(n)$ & $\mathrm{EC}_{50}(\mathrm{nM}) \pm$ S.E.M. $(n)$ & $\mathrm{EC}_{50}(\mathrm{nM}) \pm$ S.E.M. $(n)$ \\
\hline & $\%$ Max DAMGO Stimulation \pm S.E.M. & \% Max U69,593 Stimulation \pm S.E.M. & $\%$ Max DPDPE Stimulation \pm S.E.M. \\
\hline \multirow[t]{2}{*}{ Fentanyl } & $18 \pm 4(12)$ & $389 \pm 41(14)$ & $1256 \pm 153(13)$ \\
\hline & $92 \% \pm 4 \%$ & $85 \% \pm 5 \%$ & $71 \% \pm 5 \%$ \\
\hline \multirow[t]{2}{*}{ Morphine } & $38 \pm 6(13)$ & $47 \pm 6(12)$ & $789 \pm 92(13)$ \\
\hline & $86 \% \pm 3 \%$ & $94 \% \pm 4 \%$ & $89 \% \pm 4 \%$ \\
\hline
\end{tabular}

hDOR, human $\delta$ opoid receptor; hKOR, human $\kappa$ opioid receptor; $n$, number of independent experiments, each conducted with duplicate determinations; rMOR; rat $\mu$ opioid receptor.

of F/FAs on animal models of FIMR and FIRE can be blocked with non-MOR antagonists, point to new directions for the development of treatments for the effects of synthetic opioids.

\section{Materials and Methods}

Drugs and Chemicals. Fentanyl, carfentanil, morphine, and naloxone were obtained from the Drug Supply Program, National Institute on Drug Abuse (Rockville, MD). Norepinephrine, epinephrine, phenylephrine, prazosin, and tamsulosin were obtained from Sigma-Aldrich Chemical Co. (St. Louis, MO).

$\left[{ }^{3} \mathrm{H}\right]$ 8-OH-DPAT, $\left[{ }^{3} \mathrm{H}\right]$ 7-chloro-3-methyl-1-phenyl-1,2,4,5-tetrahydro-3-benzazepin-8-ol (SCH23390), [ $\left.{ }^{125} \mathrm{I}\right]$ methyl (1R,2S,3S)-3-(4-iodophenyl)-8-methyl-8-azabicyclo [3.2.1] octane-2-carboxylate) (RTI-55), $\left[{ }^{3} \mathrm{H}\right]$ dopamine, $\left[{ }^{3} \mathrm{H}\right] 5 \mathrm{HT},\left[{ }^{3} \mathrm{H}\right]$ prazosin, $\left[{ }^{3} \mathrm{H}\right]$ spiperone, $\left[{ }^{3} \mathrm{H}\right] \mathrm{CP}-55,940$, $\left[{ }^{3} \mathrm{H}\right] \mathrm{MK}-801, \quad\left[{ }^{3} \mathrm{H}\right]$ dihydrotetrabenazine, and $\left[{ }^{3} \mathrm{H}\right]$ norepinephrine, were purchased from Perkin Elmer Life and Analytical Sciences (Boston, MA).

All other commonly used reagents were obtained from commercial sources except where specified.

Tissue Culture. Human embryonic kidney cells (HEK-293) or Chinese hamster ovary $(\mathrm{CHO})$ cells were cultured and transfected with the respective recombinant human receptor, rat receptor (MOR), or human transporter by using modifications of previously described methods (Eshleman et al., 1999; Eshleman et al., 2013).

Receptor Binding Assays. Radioligand binding to the VMAT2 (Eshleman et al., 2013; Provencher et al., 2018); dopamine D1, D2, D3, and D4.4 receptors (Eshleman et al., 2013; Janowsky et al., 2014); 5HT 1A, 2A, 2B, and 2C receptors (Eshleman et al., 2013, 2018); and the dopamine, norepinephrine, and serotonin transporters (Eshleman et al., 1999, 2013) were conducted as previously described. Methods used to examine drug interactions with additional receptors are described below.

$\alpha_{1}$-Adr Subtypes. To characterize opioid and other drug interactions with the alpha 1 adrenergic receptor subtypes, human embryonic kidney cells expressing the recombinant human $\alpha_{1 \mathrm{~A}}$ adrenergic receptor (HEK- $\alpha_{1 \mathrm{~A}}$-Adr), human $\alpha_{1 \mathrm{~B}}$ adrenergic receptor (HEK- $\alpha_{1 \mathrm{~B}}$-Adr), or the human $\alpha_{1 \mathrm{D}}$ adrenergic receptor (HEK- $\alpha_{1 \mathrm{D}}-\mathrm{Adr}$ ) were grown in Dulbecco's modified Eagle's medium (DMEM) supplemented with $10 \%$ FetalClone, $300 \mu \mathrm{g} / \mathrm{ml} \mathrm{G} 418$, and $0.05 \%$ penicillin/ streptomycin. The source and plasmid for the receptor cDNAs were Bloomsburg University cDNA Resource Center (Bloomsburg, PA), pcDNA3.1+ $\left(\alpha_{1 \mathrm{~A}}-\mathrm{Adr}, \alpha_{1 \mathrm{~B}}-\mathrm{Adr}\right)$, and $\alpha_{1 \mathrm{D}}$-Adr (Genscript, pcDNA3.1+). HEK-293 cells were stably transfected by using modifications of our previously described methods (Shi et al., 2016).

Confluent cells (150-mm plate) were rinsed with PBS, scraped into PBS, and centrifuged for 10 minutes at $1000 \mathrm{~g}$ and $4^{\circ} \mathrm{C}$. The pellet was resuspended and polytronned in Tris buffer $\left(\mathrm{pH} 7.4\right.$ at $4^{\circ} \mathrm{C}$ ) and centrifuged at $30,000 \mathrm{~g}$ for 15 minutes at $4^{\circ} \mathrm{C}$. The Tris wash was repeated. Cells were resuspended in $3 \mathrm{ml}$ of Tris and stored at $-80^{\circ} \mathrm{C}$ until needed. The binding assay, adapted from published methods (Yang et al., 1998), was performed in duplicate in a 96-well plate. Serial dilutions of test compounds were made by using the Biomek 4000 robotics system (Beckman Coulter, Brea, CA) and assay buffer (50 mM Tris buffer, $\mathrm{pH} 7.4$ at $25^{\circ} \mathrm{C}$, containing $0.2 \mathrm{mg} / \mathrm{ml}$ ascorbic acid and $100 \mu \mathrm{M}$ tropolone). The resuspension volumes for each cell line were as follows: $\alpha_{1 \mathrm{~A}}$-Adr, 1 plate/ $6.5 \mathrm{ml}$ buffer; $\alpha_{1 \mathrm{~B}}$-Adr, one plate/ $10 \mathrm{ml}$ buffer; and $\alpha_{1 \mathrm{D}} \mathrm{Adr}$, two plates $/ 6.5 \mathrm{ml}$ buffer. Membranes were preincubated with drugs for 10 minutes prior to addition of $\left[{ }^{3} \mathrm{H}\right]$ prazosin (1 to $2 \mathrm{nM}$ final concentration, $80 \mathrm{Ci} / \mathrm{mmol}$; Perkin Elmer) in a final volume of $250 \mu \mathrm{l}$. Nonspecific binding was defined with $10 \mu \mathrm{M}$ phentolamine. The reaction was incubated for 45 minutes at $25^{\circ} \mathrm{C}$ and terminated by filtration over $0.05 \%$ polyethylenimine-soaked " $\mathrm{A}$ " filtermats by using cold Tris buffer $(50 \mathrm{mM}, \mathrm{pH}$ 7.4) with a 6 -second wash. Validation compounds included norepinephrine, epinephrine, phenylephrine, prazosin, phentolamine, and tamsulosin. The filters were dried, spotted with scintillation cocktail, and counted for 2 minutes after a 4-hour interval on a Perkin Elmer microbetaplate counter.

Opioid Receptor Subtypes. To characterize drug effects on radioligand binding to human $\delta$ and $\kappa$ opioid receptors (DORs and KORs, respectively) transfected into CHO cells (provided by SRI) and rat MOR transfected into CHO cells (provided by Dr. Thomas Murray), cell lines were maintained in DMEM supplemented with $10 \%$ FBS,

\section{TABLE 2}

$\left[{ }^{3} \mathrm{H}\right]$ Prazosin saturation binding to HEK- $\alpha_{1 \mathrm{~A}}-\mathrm{Adr}$, HEK- $\alpha_{1 \mathrm{~B}}$-Adr, and HEK- $\alpha_{1 \mathrm{D}}$-Adr receptor subtypes: $\left[{ }^{3} \mathrm{H}\right]$ Prazosin $\mathrm{K}_{\mathrm{D}}$ and $B_{\text {max }}$ values $\left[{ }^{3} \mathrm{H}\right]$ Prazosin was tested at concentrations ranging from 0.08 to $2.5 \mathrm{nM}$. Assays were conducted in duplicate. Experiments were conducted as described in the text.

\begin{tabular}{lcc}
\hline Receptor & {$\left[{ }^{3} \mathrm{H}\right]$ Prazosin Binding } & $\mathrm{K}_{\mathrm{D}}(\mathrm{nM}) \pm \mathrm{S} . \mathrm{E} . \mathrm{M}$. \\
\hline$\alpha_{1 \mathrm{~A}} \mathrm{Adr}$ & $B_{\max }(\mathrm{pmol} / \mathrm{mg}) \pm$ S.E.M. $(n)$ & $0.153 \pm 0.052$ \\
$\alpha_{1 \mathrm{~B}}$-Adr & $6.39 \pm 0.30(3)$ & $0.147 \pm 0.018$ \\
$\alpha_{1 \mathrm{D}}$-Adr & $7.7 \pm 1.7(3)$ & $0.186 \pm 0.003$ \\
\hline
\end{tabular}

$n$, number of independent experiments, each conducted with duplicate determinations. 


\section{A}
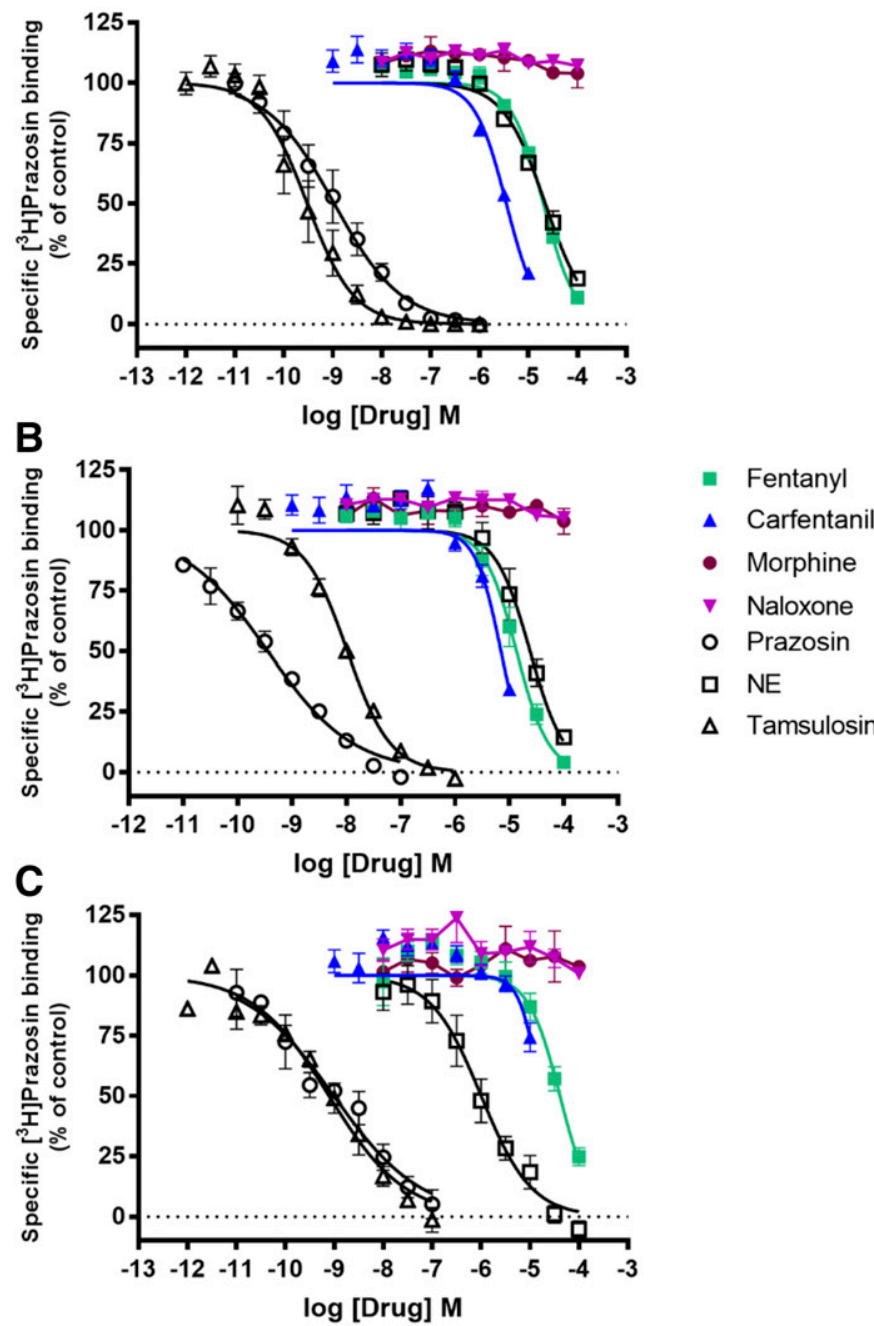

Fig. 2. Displacement of specific $\left[{ }^{3} \mathrm{H}\right]$ Prazosin binding by opioids and antagonists at $\alpha_{1 \mathrm{~A}}-\mathrm{Adr}(\mathrm{A}), \alpha_{1 \mathrm{~B}}-\mathrm{Adr}(\mathrm{B})$, and $\alpha_{1 \mathrm{D}^{-}} \mathrm{Adr}(\mathrm{C})$ receptor subtypes. Data shown are the means \pm S.E.M. of three to five experiments, except if a drug had no effect when $n=2$.

$400 \mu \mathrm{g} / \mathrm{ml} \mathrm{G} 418$, and $0.1 \%$ penicillin/streptomycin. All cell lines were grown to confluence and then harvested for membrane preparation. The membranes for binding assays were prepared in $50 \mathrm{mM}$ of Tris buffer ( $\mathrm{pH} 7.5$ at $4^{\circ} \mathrm{C}$ ). Cells were scraped from the plates in calcium/ magnesium free-PBS and centrifuged at $500 \mathrm{~g}$ for 15 minutes. The cell pellet was homogenized in $2 \mathrm{ml}$ buffer with a polytron, diluted with $11 \mathrm{ml}$ buffer, and centrifuged at 40,000g for 15 minutes; then it was washed and recentrifuged. The final pellet was covered with $3 \mathrm{ml}$ buffer and stored at $-80^{\circ} \mathrm{C}$ until needed.

Binding assays were conducted by using $\left[{ }^{3} \mathrm{H}\right]\left[\mathrm{D}-\mathrm{Ala}^{2}, N-\mathrm{MePhe}^{4}\right.$, Gly-ol]-enkephalin (DAMGO), $\left[{ }^{3} \mathrm{H}\right]\left[\mathrm{D}-\mathrm{Pen}^{2}, \mathrm{D}-\mathrm{Pen}^{5}\right]$ encephalin (DPDPE) $(0.8 \mathrm{nM}, \sim 20,000 \mathrm{cpm})$, and $\left[{ }^{3} \mathrm{H}\right](+)-(5 \alpha, 7 \alpha, 8 \beta)-N-M e t h y l-N-$ [7-(1-pyrrolidinyl)-1-oxaspiro[4.5] dec-8-yl]-benzeneacetamide $(\mathrm{U} 69,593)(0.8 \mathrm{nM}, \sim 22,000 \mathrm{cpm})$ at the MORs, DORs, and KORs, respectively. The assays were performed in duplicate in 96 -well plates by using $50 \mathrm{mM}$ Tris buffer ( $\mathrm{pH} 7.7$ at room temperature). Nonspecific binding was determined with $1.0 \mu \mathrm{M}$ of the unlabeled analog of each radioligand. Cell membranes were incubated with the appropriate radioligand and test compound at $25^{\circ} \mathrm{C}$ for 60 minutes. The incubation was terminated by rapid filtration through Perkin Elmer Filtermat A filters presoaked in $0.05 \%$ polyethylenimine on a Tomtec cell harvester, and bound radioactivity was determined as described for other receptors above. For $\left[{ }^{3} \mathrm{H}\right] \mathrm{DAMGO},\left[{ }^{3} \mathrm{H}\right] \mathrm{DPDPE}$, and $\left[{ }^{3} \mathrm{H}\right] \mathrm{U} 69,593$, the dissociation constant $\mathrm{K}_{\mathrm{D}}$ values are $0.147,0.789$, and $0.65 \mathrm{nM}$, respectively. The densities of receptors are $0.373 \pm 0.095,32.8 \pm$ 1.7 , and $11.29 \pm 0.34 \mathrm{pmol} / \mathrm{mg}$ protein for the MOR, DOR, and KOR cell lines, respectively.

CB1 Cannabinoid Receptor. The method for $\left[{ }^{3} \mathrm{H}\right] \mathrm{CP}-55,940$ binding assays was adapted from Farrens et al. (2002). The source and plasmid for the receptor cDNA was cDNA Resource Center and pcDNA3.1+. HEK-293 cells were transfected by using lipofectamine 2000 (Invitrogen). WIN 55,212 $(10 \mu \mathrm{M})$ was used to define nonspecific binding. HEK-CB1 cells were grown until confluent on 15-cm dishes. Cells were scraped into $7 \mathrm{ml}$ of calcium/magnesium free-PBS and centrifuged at $11,000 \mathrm{~g}$ for 10 minutes. The supernatant was decanted, and the pellet was resuspended with a Polytron in $5 \mathrm{ml}$ of hypotonic buffer [5 mM Tris, $2 \mathrm{mM}$ EDTA + protease inhibitors (PI)]. The homogenate was centrifuged at $35,000 \mathrm{~g}$ for 20 minutes and resuspended in TME buffer (20 mM Tris, 5 mM MgCl2, 1 mM EDTA, pH 7.4 at $4^{\circ} \mathrm{C}$ with PI) by using a Polytron. After centrifugation at $35,000 \mathrm{~g}$ for 20 minutes, the pellet was resuspended in TME + PI buffer $(1.6-3 \mathrm{ml}$ for competition or saturation binding assay) by using a Polytron. Proteins were quantified by using the BCA kit (Thermo Fisher, Waltham, MA).

Binding assays used TME supplemented with $5 \mathrm{mg}$ bovine serum albumin $(\mathrm{BSA}) / \mathrm{ml}, \mathrm{pH} 7.4$, at $30^{\circ} \mathrm{C}$. The reaction included test compounds or WIN-55,212, membrane preparation $(15-70 \mu \mathrm{g}$, depending on the expression level of CB1), $\left[{ }^{3} \mathrm{H}\right] \mathrm{CP}-55,940$, and TME 


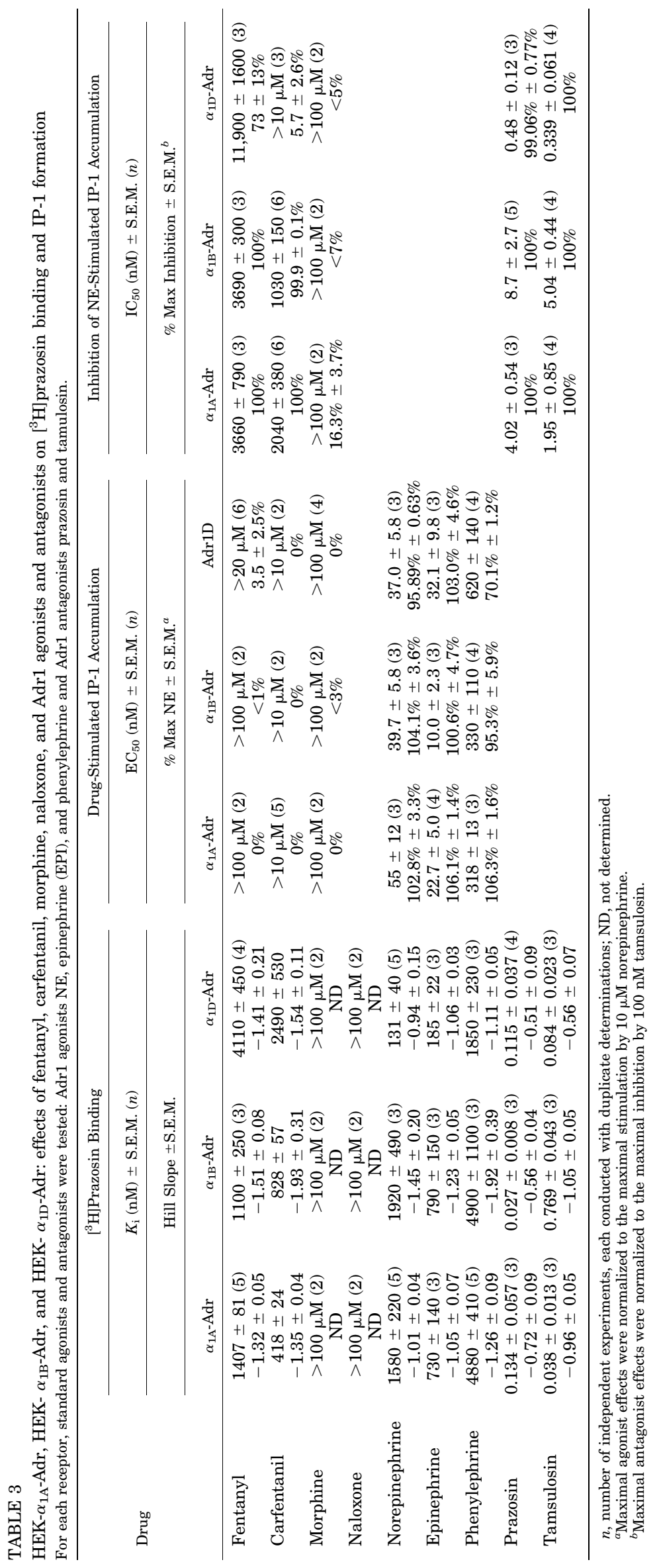



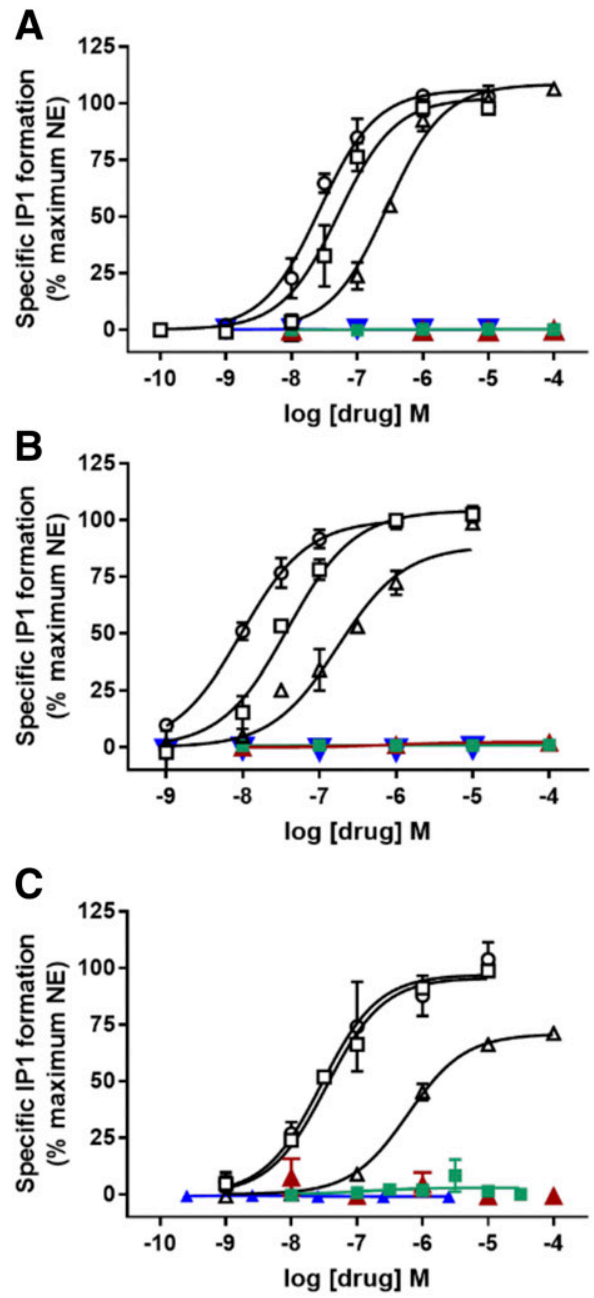
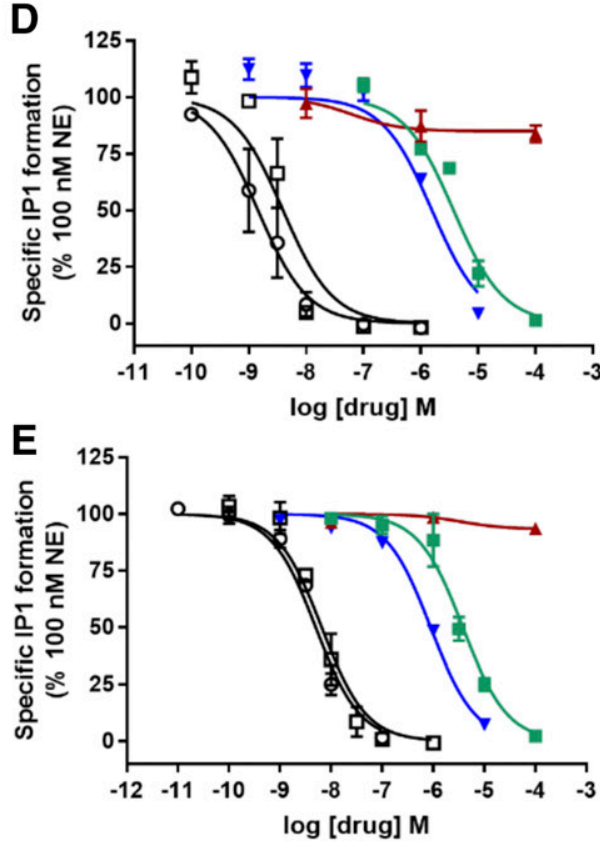

- Fentanyl

\ Morphine

$\checkmark$ Carfentani

口 Prazosin

- Tamsulosin

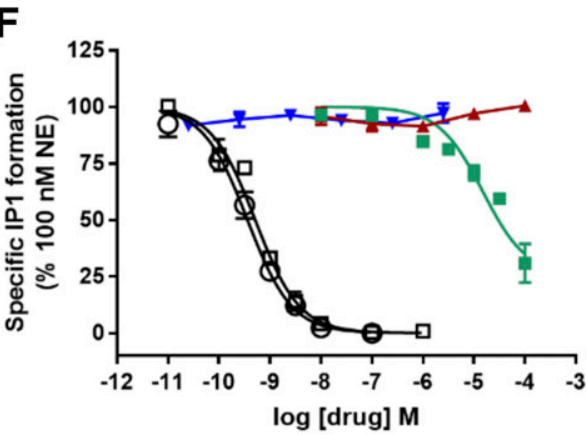

Fig. 3. HEK- $\alpha_{1 \mathrm{~A}}$-Adr, HEK- $\alpha_{1 \mathrm{~B}}-\mathrm{Adr}$, and HEK- $\alpha_{1 \mathrm{D}}$-Adr: IP-1 agonist and antagonist dose-response curves. Agonist stimulation of IP-1 formation of $\alpha_{1 \mathrm{~A}}-\mathrm{Adr}(\mathrm{A}), \alpha_{1 \mathrm{~B}}-\mathrm{Adr} 1 \mathrm{~B}(\mathrm{~B})$, and (C) $\alpha_{1 \mathrm{D}}$-Adr receptor subtypes. Antagonist inhibition of norepinephrine-stimulated IP-1 formation of $\alpha_{1 \mathrm{~A}}$-Adr (D), $\alpha_{1 \mathrm{~B}}-\mathrm{Adr}(\mathrm{E})$, and $\alpha_{1 \mathrm{D}}-\mathrm{Adr}(\mathrm{F})$ receptor subtypes. Data shown are the means \pm S.E.M. of three to six experiments, except if a drug had no effect when $n=2$.

+ BSA buffer to a final volume of $0.5 \mathrm{ml}$. In saturation binding assays, the range of concentrations of $\left[{ }^{3} \mathrm{H}\right] \mathrm{CP}-55,940$ was $0.07-3 \mathrm{nM}$. In competition binding assays, the concentration of $\left[{ }^{3} \mathrm{H}\right] \mathrm{CP}-55,940$ was $1.2-1.5 \mathrm{nM}$. After incubation at $30^{\circ} \mathrm{C}$ for 60 minutes, the reaction was terminated by filtration with $\mathrm{TME}+1 \mathrm{mg} \mathrm{BSA} / \mathrm{ml}$ over Filtermat A filters presoaked in $0.2 \%$ polyethylenimine. An additional wash was added to the normal harvesting program to reduce nonspecific binding.

NMDA Receptor Binding. The methods were adapted from Grant et al. (1997). For functional NMDA receptors, cells need to express two NMDA receptor subunits, the GluN1a and the GluN2a. However, simultaneous and stable expression of both subunits is toxic to the cell (Grant et al., 1997; unpublished results). We developed a method by using a cell line that stably expresses one of the subunits (GluN2a) and is subsequently transfected with the cDNA for the other subunit (GluN1a) the week of the experiment.

HEK cells stably expressing the GluN2a subunit (G2a-Myc cDNA; Origene) were transfected with $10 \mu \mathrm{g}$ of Grin1-tGFP cDNA (Origene), using the polyethylenimine as we have previously described (Shi et al., 2016). On day 2, medium was changed to DMEM supplemented with selection antibiotic G418 ( $300 \mu \mathrm{g} / \mathrm{ml})$. To reduce coexpression toxicity, the receptors were blocked with $100 \mu \mathrm{M}$ of ketamine (adapted from Grant et al., 1997) and incubated for 48 hours. On day 4, cells were harvested by pouring off the medium and rinsing with $10 \mathrm{ml}$ of HEPES buffer $(20 \mathrm{mM})$, and each plate of cells was scraped into $10 \mathrm{ml}$ of high
Mg2+ buffer (20 mM HEPES, $100 \mu \mathrm{M}$ glycine, $100 \mu \mathrm{M}$ glutamate, $300 \mu \mathrm{M} \mathrm{MgCl} 2, \mathrm{pH}$ 7.5). To remove the ketamine, cells were incubated for 30 minutes at $32^{\circ} \mathrm{C}$ and centrifuged for 10 minutes at $48,000 \mathrm{~g}$ at $4^{\circ}$ C. EDTA buffer (20 mM HEPES, $1 \mathrm{mM}$ EDTA, pH 7.5) was added, the pellet was homogenized by using a Polytron, and the membranes were incubated for 30 minutes at $32^{\circ} \mathrm{C}$. After centrifugation, the pellet was polytronned in $\sim 3 \mathrm{ml}$ assay buffer $(20 \mathrm{mM}$ HEPES, $100 \mu \mathrm{M}$ glycine, $100 \mu \mathrm{M}$ glutamate, $100 \mu \mathrm{M} \mathrm{MgCl} 2,0.2 \mathrm{mg} / \mathrm{ml}$ ascorbic acid, $\mathrm{pH}$ 7.5).

The binding assay included drug, membrane preparation, $\left[{ }^{3} \mathrm{H}\right] \mathrm{MK}-$ $801(\sim 20 \mathrm{nM})$, and assay buffer in a final volume of $250 \mu \mathrm{l}$. Specific binding was defined as the difference between total binding and nonspecific binding in the presence of $10 \mu \mathrm{M}$ unlabeled MK-801. The reaction was incubated for 60 minutes at $22^{\circ} \mathrm{C}$ and was terminated by filtration with $20 \mathrm{mM}$ of ice-cold HEPES buffer, $\mathrm{pH} 7.5$, through Perkin Elmer A filtermats presoaked in $0.5 \%$ polyethylenimine, using a Tomtec 96 -well harvester. Radioactivity remaining on filters was counted in a Perkin Elmer microbetaplate reader.

Assays of Function. Assays of VMAT2 function (Eshleman et al., 2013; Provencher et al., 2018), dopamine D1 and D4.4 receptor function (Eshleman et al., 2013; Janowsky et al., 2014), and $\left[{ }^{3} \mathrm{H}\right]$ neurotransmitter uptake by the dopamine, norepinephrine, and serotonin transporters (Eshleman et al., 1999, 2013) were conducted as we have previously described in detail. Methods used to examine drug effects on other receptor-mediated signal transduction pathways are described below. 


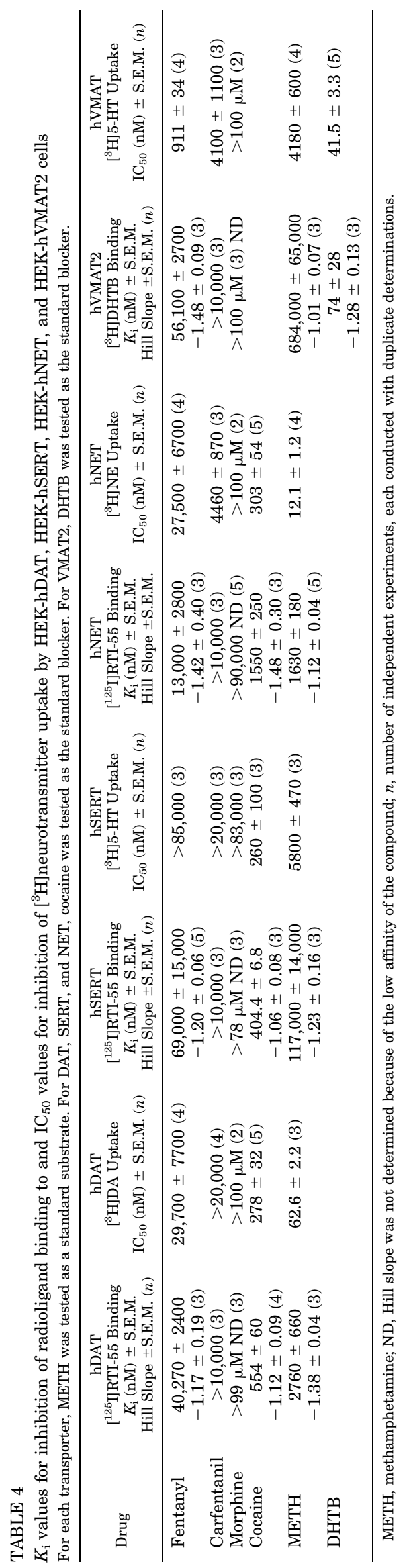

$\alpha_{1}$-Adr-Mediated Inositol-1-Phosphate Formation. HEK$\alpha_{1 \mathrm{~A}}$-Adr, HEK- $\alpha_{1 \mathrm{~B}}-\mathrm{Adr}$, or HEK- $\alpha_{1 \mathrm{D}}$-Adr cells were used for assays involving the IP-One Gq ELISA kit (CisBio, Bedford, MA). The methods are an adaptation of our 5HT2A inositol-1-phosphate (IP-1) assay (Eshleman et al., 2013). The day before an experiment, cells were plated in 24 -well plates at a density of 400,000 cells/well by using DMEM supplemented with charcoal-stripped FetalClone and penicillin/streptomycin. For HEK- $\alpha_{1 \mathrm{~A}}$-Adr cells, on the day of the experiment, medium was removed and cells were preincubated with $1 \mathrm{ml}$ of unsupplemented medium for 1 hour. HEK- $\alpha_{1 \mathrm{~B}}$-Adr or HEK- $\alpha_{1 \mathrm{D}}$-Adr cells were used without rinsing. Drugs were made up in stimulation buffer supplied in the kit supplemented with $100 \mu \mathrm{M}$ of tropolone. Medium was removed from the well, antagonist or buffer was added, and cells were preincubated for 10 minutes. Agonists were added, cells were incubated for 1 hour and lysed for 30 minutes, and $50 \mu \mathrm{l}$ of cell lysate was added to the IP-1 plates. After the addition of appropriate antibodies, plates were incubated overnight at $4^{\circ} \mathrm{C}$, washed six times, and incubated with substrate for 20 minutes, and after termination of the reaction, the plate was read on a plate reader at $450 \mathrm{~nm}$ with a correction at $620 \mathrm{~nm}$. Agonist effects were normalized to the maximal stimulation by norepinephrine, and antagonists were tested in the presence of $100 \mathrm{nM}$ norepinephrine and normalized to the inhibition by $100 \mathrm{nM}$ tamsulosin.

Opioid ( $\delta$ and $\kappa$ ) Receptor-Mediated $\left[{ }^{35} \mathbf{S}\right]$ GTP $\gamma$ S Binding. The membranes for $\left[{ }^{35} \mathrm{~S}\right] \mathrm{GTP} \gamma \mathrm{S}$ binding assays were prepared in $20 \mathrm{mM}$ of HEPES, $10 \mathrm{mM}$ of $\mathrm{MgCl}_{2}, 100 \mathrm{mM}$ of $\mathrm{NaCl}$, and $0.2 \mathrm{mM}$ of dithiothreitol (pH 7.4). Cells were scraped from the plates and centrifuged at $500 \mathrm{~g}$ for 15 minutes. The resulting pellet was homogenized in $2 \mathrm{ml}$ of buffer with a polytron, diluted with $11 \mathrm{ml}$ of buffer, centrifuged at $40,000 \mathrm{~g}$ for 15 minutes, and washed and recentrifuged. The final pellet was covered with $3 \mathrm{ml}$ of buffer and stored at $-80^{\circ} \mathrm{C}$ until needed. The membranes were incubated with $\left[{ }^{35} \mathrm{~S}\right] \mathrm{GTP} \gamma \mathrm{S}(50 \mathrm{pM})$, GDP $(10 \mu \mathrm{M})$, and the test compound in a total volume of $1 \mathrm{ml}$ for 60 minutes at $25^{\circ} \mathrm{C}$ (Traynor and Nahorski, 1995). Samples were filtered over Perkin Elmer FiltermatA filters and counted as described for the binding assays. A dose response curve with a prototypical full agonist (DPDPE and U69,593 for DORs and KORs, respectively) was conducted in each experiment to identify full and partial agonists.

Opioid $(\mu)$ Receptor-Mediated $\left[{ }^{35} \mathbf{S}\right] \mathbf{G T P} \gamma \mathbf{S}$ Binding. Comparisons of morphine-like and synthetic opioids on $\beta$-arrestin 2 have been well described (de Waal et al., 2020; Vasudevan et al., 2020). Fentanyl and related analogs, as well as morphine-like compounds, exert effects via a $\beta$-arrestin 2-mediated pathway that is hypothesized to play a role in the unwanted side effects of opioids. Here, we executed a head-to-head comparison of the effects of morphine and fentanyl on opioid receptormediated $\mathrm{G} \alpha_{\mathrm{i} / \mathrm{o}}$ activation as well as effects on nonopioid receptor function. Membranes were prepared in $20 \mathrm{mM}$ of HEPES, $10 \mathrm{mM}$ of $\mathrm{MgCl}_{2}, 100 \mathrm{mM}$ of $\mathrm{NaCl}, 1 \mathrm{mM}$ of EDTA, and $0.2 \mathrm{mM}$ of dithiothreitol (pH 7.4). Cells were starved for 12-18 hours prior to harvest in unsupplemented DMEM. Cells were scraped from the plates and centrifuged at $500 \mathrm{~g}$ for 15 minutes. The cell pellet was homogenized in $2 \mathrm{ml}$ of buffer with a polytron, diluted with $11 \mathrm{ml}$ of buffer, centrifuged at $40,000 \mathrm{~g}$ for 15 minutes, and washed and recentrifuged. The final pellet was overlaid with $3 \mathrm{ml}$ of buffer and stored at $-80^{\circ} \mathrm{C}$ until use. For agonist assays, the membrane was incubated with $\left[{ }^{35} \mathrm{~S}\right] \mathrm{GTP} \gamma \mathrm{S}(50$ $\mathrm{pM}), \mathrm{GDP}(1 \mu \mathrm{M})$, and the test compound in a total volume of $1 \mathrm{ml}$ for 60 minutes at $25^{\circ} \mathrm{C}$. Samples were filtered over glass fiber filters and washed with ice-cold saline. A dose-response curve with DAMGO was conducted in each agonist experiment to identify full and partial agonist compounds.

Data Analysis. Sigmoidal curves resulting in $\mathrm{IC}_{50}$ values for displacement of radioligand or inhibition of second messenger generation were analyzed by using a nonlinear curve-fitting program and further analyzed by using unpaired $t$ tests or one-way ANOVAs followed by either Dunnett's or Tukey's multiple comparisons test (Prism version 7; GraphPad Software, La Jolla, CA). Saturation binding data were analyzed by nonlinear regression to generate $K_{D}$ 
A
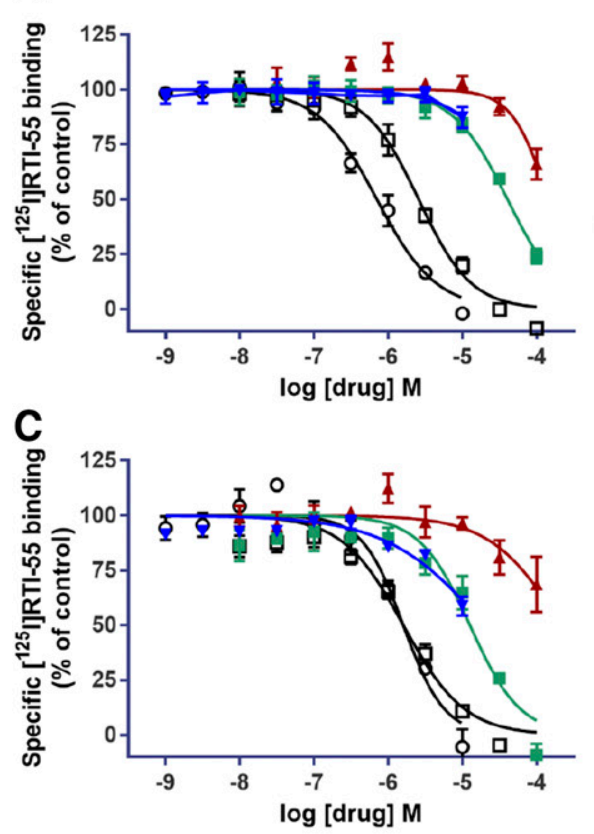

B
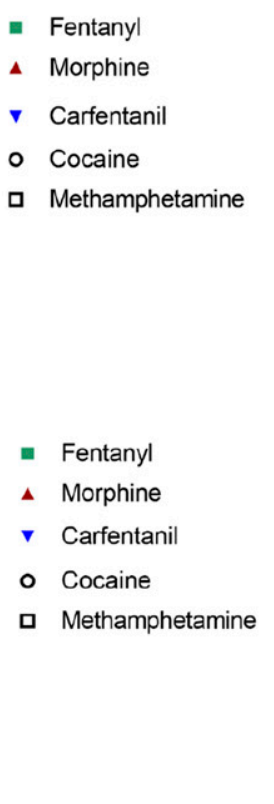
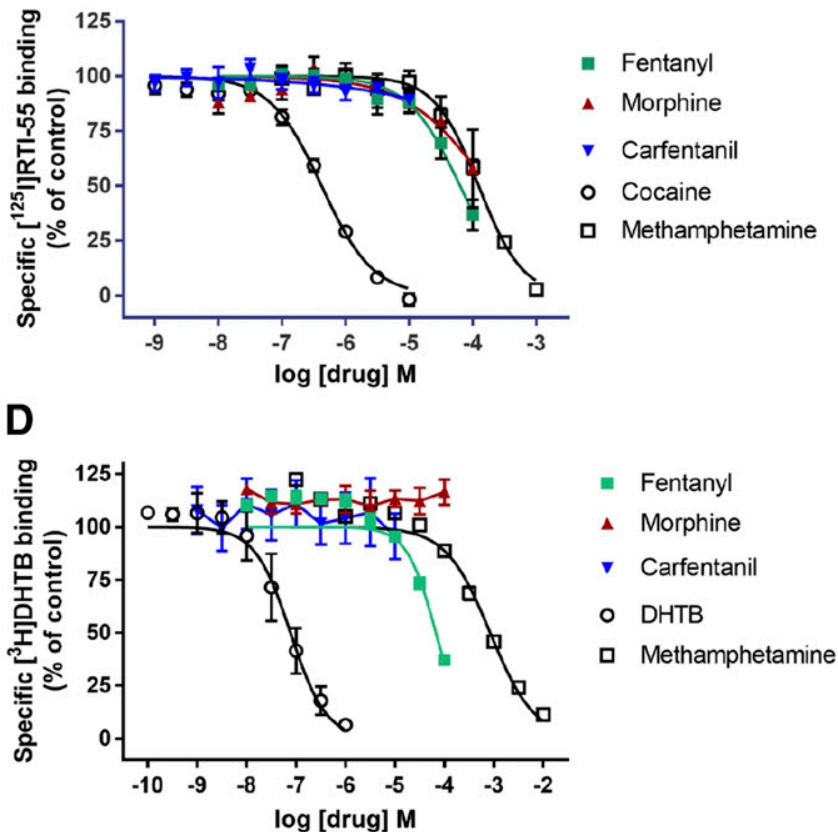

Fig. 4. Opioid effects on radioligand binding to transporters. ([ $\left.\left.{ }^{125} \mathrm{I}\right] \mathrm{RTI}-55\right)$ binding to HEK-hDAT (A), hSERT (B), and hNET (C). (D) $\left[{ }^{3} \mathrm{H}\right] \mathrm{DHTB}$ binding to hVMAT2. Data shown are the means \pm S.E.M. of three to five experiments, except if a drug had no effect when $n=2$.

and $B_{\max }$ values as we have previously described (Eshleman et al., 2013, 2018; Janowsky et al., 2014).

\section{Results}

Fentanyl and Morphine Interactions with Opioid Receptor Subtypes. Fentanyl and morphine (Fig. 1) had highest affinity for MOR ( $\left[{ }^{3} \mathrm{H}\right] \mathrm{DAMGO}$ binding), as compared with their affinities for KOR and DOR subtypes, and the rank order of affinities across receptors were similar $(\mu>>\kappa>\delta)$ (Table 1). However, fentanyl had higher selectivity, i.e., its affinities for KOR (357-fold) and DOR (697-fold) were much lower than its affinity for the MOR compared with morphine, which differed less in affinities for the KORs (46-fold) and DORs (306-fold). In assays of receptor function $\left({ }^{35} \mathrm{~S}\right] \mathrm{GTP} \gamma \mathrm{S}$ binding), potency differences paralleled affinity differences in
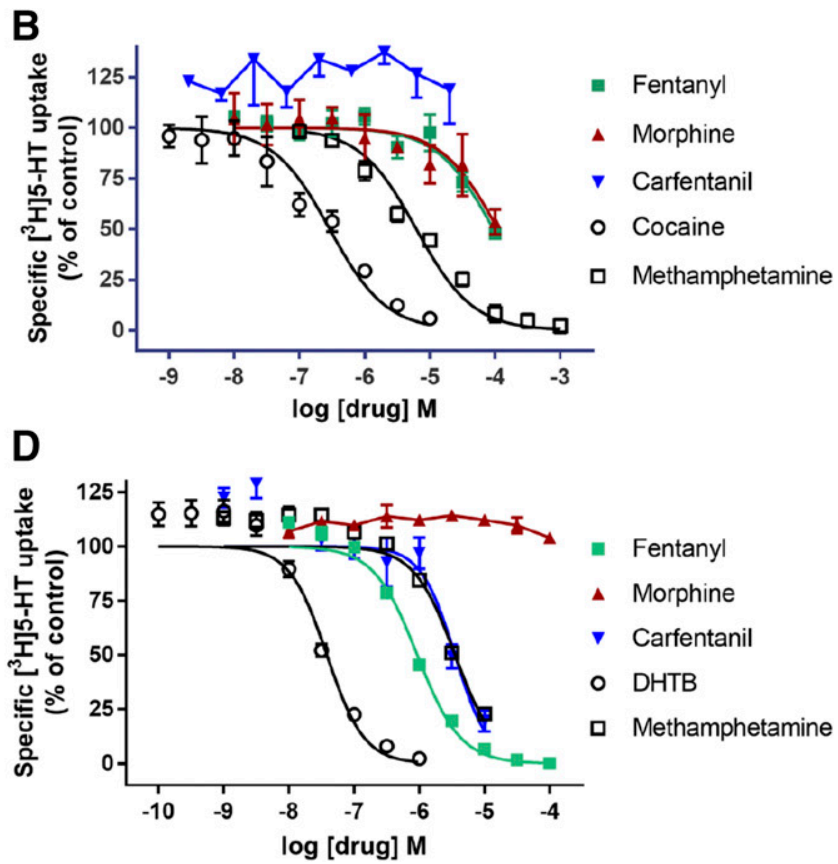

Fig. 5. Opioid effects on $\left[{ }^{3} \mathrm{H}\right]$ neurotransmitter uptake by HEK-hDAT, -hSERT, -hNET, and -hVMAT2. (A) hDAT $\left(\left[{ }^{3} \mathrm{H}\right]\right.$ dopamine); (B) hSERT $\left(\left[{ }^{3} \mathrm{H}\right]\right.$ 5-HT); (C) hNET $\left(\left[{ }^{3} \mathrm{H}\right] \mathrm{NE}\right)$; (D) hVMAT2 $\left({ }^{3} \mathrm{H}\right]$ 5-HT). Data shown are the means \pm S.E.M. of three to five experiments, except if a drug had no effect when $n=2$. 
TABLE 5

Drug effects on radioligand binding to dopamine D1, D2, D3, and D4.4 receptors

For each receptor, a standard agonist (SKF38393 or quinpirole) and antagonist (SCH23390, butaclamol, or haloperidol) was tested.

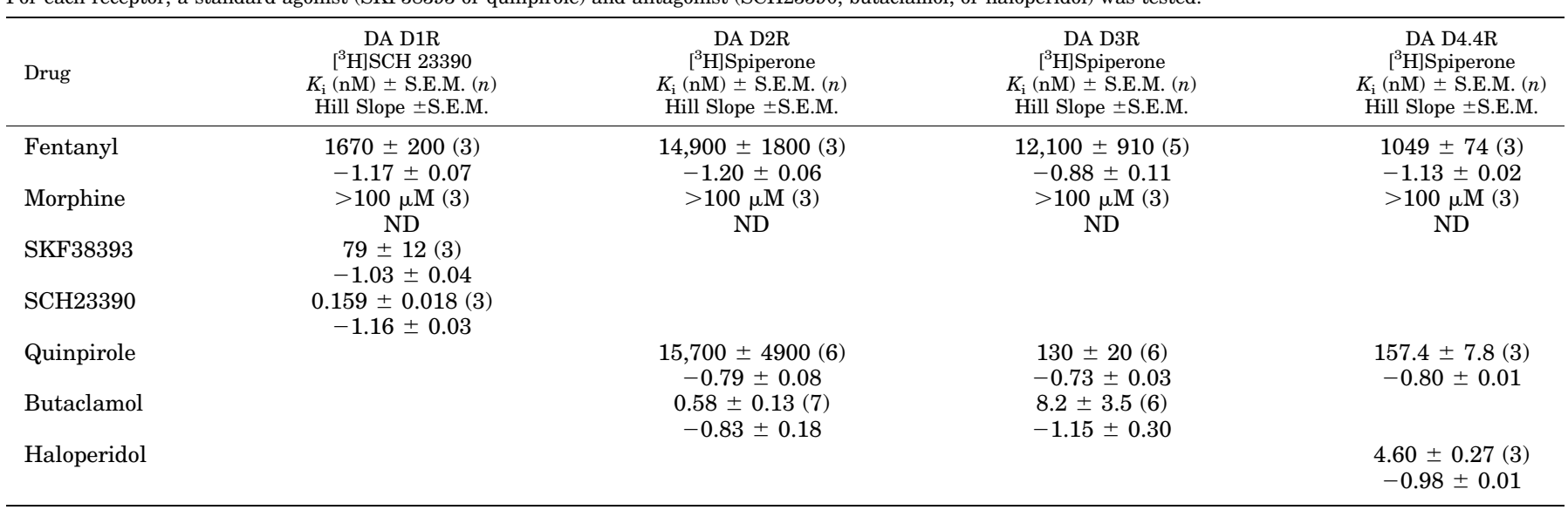

$n$, number of independent experiments, each conducted with duplicate determinations; ND, not determined.

terms of selectivity. Fentanyl was an apparent full agonist at the MOR but, under the assay conditions described here, was a partial agonist at DOR (71\% efficacy compared with DPDPE, $P<0.0001$, one-way ANOVA followed by Dunnett's multiple comparison test) and $\mathrm{KOR}(85 \%$ compared with $\mathrm{U} 50,488 \mathrm{H}$, $P<0.05)$. Morphine, however, was a full agonist at KOR but a partial agonist at $\operatorname{DOR}(P<0.05)$ and $\operatorname{MOR}(P<0.01)$ (Table 1).

Fentanyl, Carfentanil, Morphine, and Naloxone Interactions with $\alpha_{\mathbf{1}}$-Adr Subtypes. In initial experiments, equilibrium saturation binding of $\left[{ }^{3} \mathrm{H}\right]$ prazosin to recombinant human $\alpha_{1 \mathrm{~A}}-\mathrm{Adr}, \alpha_{1 \mathrm{~B}}-\mathrm{Adr}$, and $\alpha_{1 \mathrm{D}}-\mathrm{Adr}$ subtypes stably expressed in HEK293 cells was characterized, and $\mathrm{K}_{\mathrm{D}}$ and $B_{\max }$ values were determined (Table 2). For $\alpha_{1 \mathrm{~A}}-\mathrm{Adr}$, the $\left.{ }^{3} \mathrm{H}\right]$ prazosin $\mathrm{K}_{\mathrm{D}}$ was $0.153 \pm 0.052 \mathrm{nM}$ and the $B_{\max }$ was 6.39 $\pm 0.3 \mathrm{pmol} / \mathrm{mg}$ protein. For $\alpha_{1 \mathrm{~B}}-\mathrm{Adr}$, the $\mathrm{K}_{\mathrm{D}}$ was $0.147 \pm 0.018$ $\mathrm{nM}$ and the $B_{\max }$ was $7.7 \pm 1.7 \mathrm{pmol} / \mathrm{mg}$ protein. For $\alpha_{1 \mathrm{D}}-\mathrm{Adr}$, the $\mathrm{K}_{\mathrm{D}}$ was $0.186 \pm 0.003 \mathrm{nM}$ and the $B_{\max }$ was $1.12 \pm 0.18$ $\mathrm{pmol} / \mathrm{mg}$ protein. Thus, the $\mathrm{K}_{\mathrm{D}}$ values across receptor subtypes were in the high picomolar range but differed significantly (one-way ANOVA followed by Tukey's multiple comparison test, $P<0.05$ ). These $\mathrm{K}_{\mathrm{D}}$ values were used to
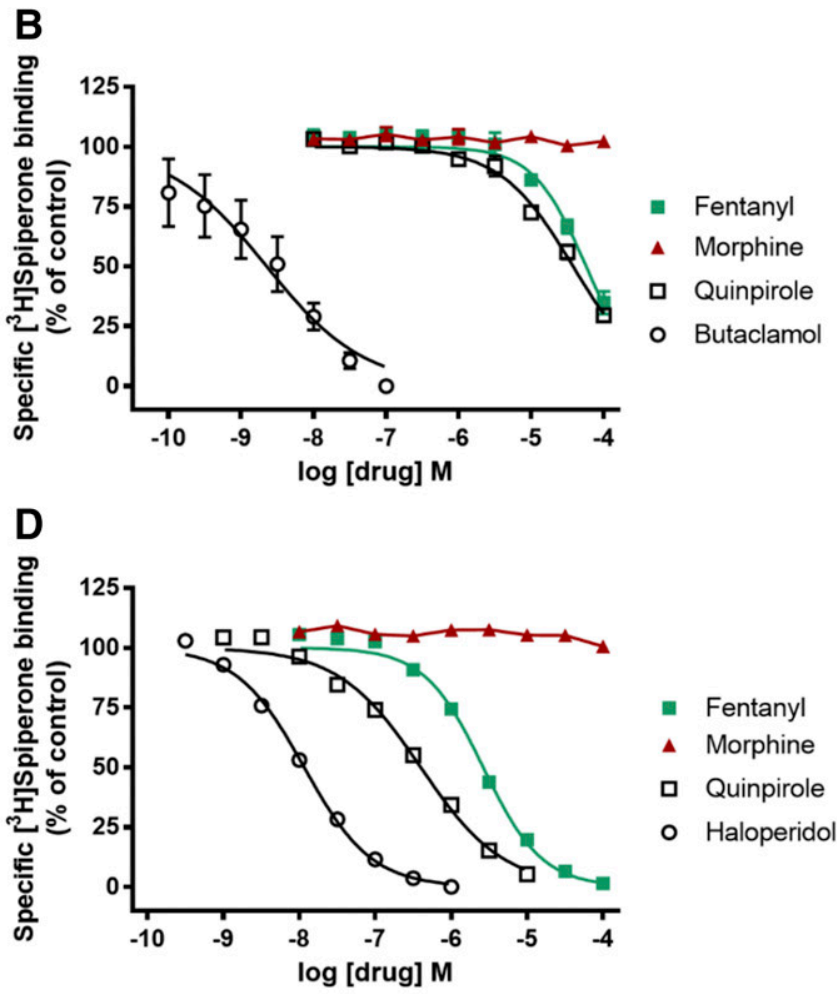

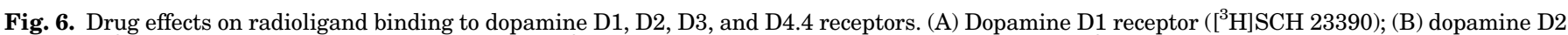

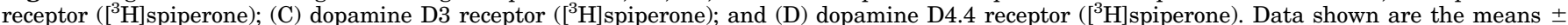
S.E.M. of three to seven experiments. 
TABLE 6

Effects of fentanyl and morphine on recombinant human dopamine D1 and D4.4 receptor function

Assays were run in duplicate with six to seven concentrations of the test compound. The standard agonist dopamine was tested in the agonist experiments, and the antagonists SCH23390 (D1) or haloperidol (D4.4) were tested in the antagonist experiment.

\begin{tabular}{|c|c|c|c|c|}
\hline Drug (Agonists) & $\begin{array}{c}\text { C6-D1 } \\
\text { EC }_{50}(\mathrm{nM}) \pm \text { S.E.M. }(n) \\
\% \text { Max Dopamine } \pm \text { S.E.M. }\end{array}$ & $\begin{array}{l}\text { C6-D1 } \\
\mathrm{IC}_{50}(\mathrm{nM}) \pm \text { S.E.M. }(n) \\
\text { \% Max Inhibition of } 100 \mathrm{nM} \\
\text { Dihydrexidine } \pm \text { S.E.M. }\end{array}$ & $\begin{array}{c}\text { HEK-D4.4-AC1 } \\
\text { EC }_{50}(\mathrm{nM}) \pm \text { S.E.M. }(n) \\
\% \text { Max Quinpirole } \pm \text { S.E.M. }\end{array}$ & $\begin{array}{l}\text { HEK-D4.4-AC1 } \\
\text { IC }_{50}(\mathrm{nM}) \pm \text { S.E.M. }(n) \\
\% \text { Max Reversal of } 100 \mathrm{nM} \\
\text { Quinpirole } \pm \text { S.E.M. }\end{array}$ \\
\hline Fentanyl & $>100 \mu \mathrm{M}(2)$ & $27,000 \pm 5500(5)$ & $\begin{array}{c}>50 \mu \mathrm{M}(6) \text { (three of six curves } \\
\text { could be fit) }\end{array}$ & $12,700 \pm 2500(4)$ \\
\hline Morphine & $\begin{array}{c}0 \% \\
>100 \mu \mathrm{M}(2)\end{array}$ & $\begin{array}{l}65.5 \% \pm 4.0 \% \\
>100 \mu \mathrm{M}(2)\end{array}$ & $\begin{array}{c}36 \% \pm 11 \% \\
>40 \mu \mathrm{M}(5) \text { (three of five curves } \\
\text { could be fit) }\end{array}$ & $\begin{array}{c}63 \% \pm 20 \% \\
>100 \mu \mathrm{M}(3)\end{array}$ \\
\hline Dopamine & $\begin{array}{c}13 \% \pm 13 \% \\
19.5 \pm 1.7 \\
91.6 \% \pm 5.9 \%\end{array}$ & $4.5 \% \pm 4.5 \%$ & $\begin{array}{c}20 \% \pm 11 \% \\
4.4 \pm 1.5(4) \\
95.1 \% \pm 1.8 \%\end{array}$ & Minimal effect \\
\hline Quinpirole & & & $\begin{array}{c}0.60 \pm 0.25(6) \\
95.4 \pm 3.9 \%\end{array}$ & \\
\hline SCH23390 & & $\begin{array}{c}3.90 \pm 0.52(4) \\
98.36 \% \pm 0.26 \%\end{array}$ & & \\
\hline Haloperidol & & & & $\begin{array}{l}152 \pm 55(4) \\
117 \% \pm 26 \%\end{array}$ \\
\hline
\end{tabular}

$n$, number of independent experiments, each conducted with duplicate determinations.

calculate $K_{\mathrm{i}}$ values in subsequent experiments that examined drug-receptor interactions (Cheng and Prusoff, 1973).

Fentanyl had $K_{\mathrm{i}}$ values in the low micromolar range at each receptor subtype, with a rank order of affinity of $\alpha_{1 \mathrm{~B}}-\mathrm{Adr} \geq$ $\alpha_{1 \mathrm{~A}}-\mathrm{Adr}>\alpha_{1 \mathrm{D}}$-Adr $(P<0.001$, one-way ANOVA followed by Tukey's multiple comparison, Fig. 2; Table 3). Carfentanil similarly demonstrated $K_{\mathrm{i}}$ values in the low micromolar range with a rank order of affinity of $\alpha_{1 \mathrm{~A}} \mathrm{Adr}>\alpha_{1 \mathrm{~B}}-\mathrm{Adr}>\alpha_{1 \mathrm{D}}$-Adr. In contrast, $K_{\mathrm{i}}$ values for morphine and naloxone at each receptor subtype were greater than $100 \mu \mathrm{M}$. Norepinephrine, epinephrine, and phenylephrine displaced $\left[{ }^{3} \mathrm{H}\right]$ prazosin binding with rank orders of affinity of $\alpha_{1 \mathrm{D}^{-}} \mathrm{Adr}>>\alpha_{1 \mathrm{~A}} \mathrm{Adr} \geq \alpha_{1 \mathrm{~B}^{-}}$ Adr (Table 3, $P<0.01$, one-way ANOVA followed by Tukey's multiple comparison). Importantly, fentanyl and norepinephrine, the endogenous agonist, had similar affinities for $\alpha_{1 \mathrm{~A}}-\mathrm{Adr}$ and $\alpha_{1 \mathrm{~B}}-\mathrm{Adr}(P>0.05$, one-way ANOVA followed by Dunnett's multiple comparison), whereas carfentanil had $\mathrm{a} \sim$ threefold higher affinity at $\alpha_{1 \mathrm{~A}} \mathrm{Adr}$. Carfentanil had higher affinity than norepinephrine at $\alpha_{1 \mathrm{~B}}-\mathrm{Adr}$, but both fentanyl and carfentanil had much lower affinity than norepinephrine at
A

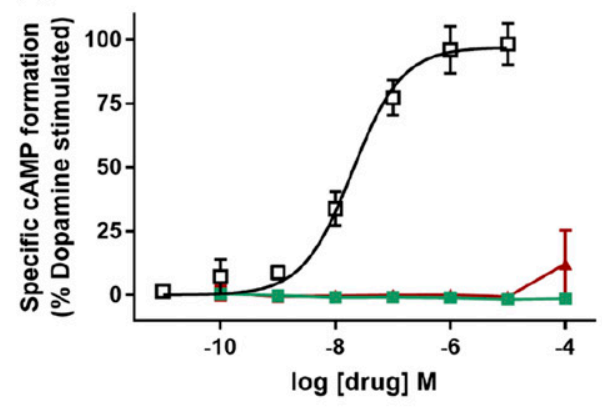

C

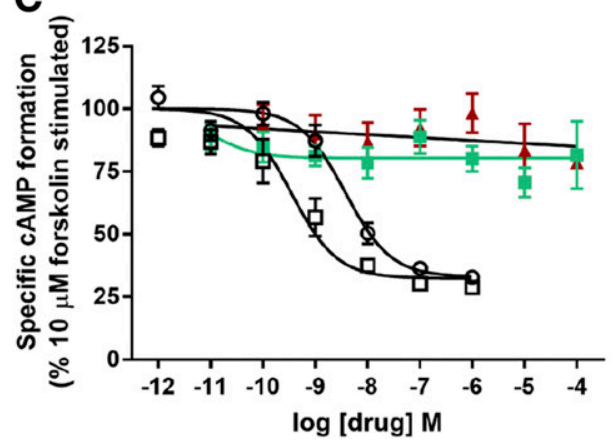

- Fentanyl

4 Morphine

口 Dopamine

- Fentanyl

\ Morphine

口 Quinpirole

○ Dopamine
B क

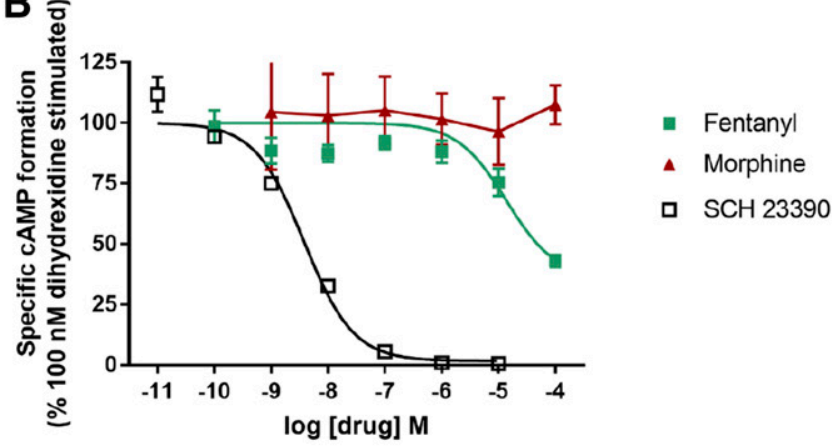

D

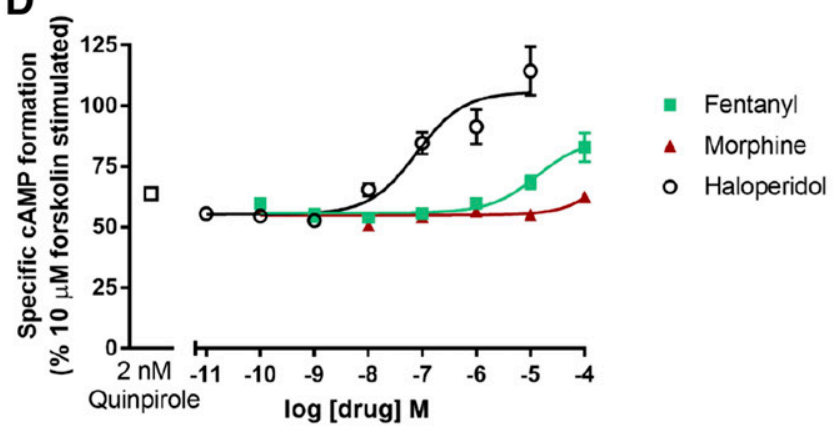

Fig. 7. Agonist, antagonist, and opioid effects on dopamine D1 and D4.4 receptor-mediated adenylyl cyclase. (A) D1 agonist stimulation of adenylyl cyclase. (B) D1 antagonist inhibition of $100 \mathrm{nM}$ dihydrexidine-stimulated adenylyl cyclase activity. (C) D4.4 agonist inhibition of $10 \mu \mathrm{M}$ forskolinstimulated adenylyl cyclase. (D) D4.4 antagonist reversal of $2 \mathrm{nM}$ quinpirole inhibition of forskolin-stimulated adenylyl cyclase. Data shown are the means \pm S.E.M. of three to six experiments. 


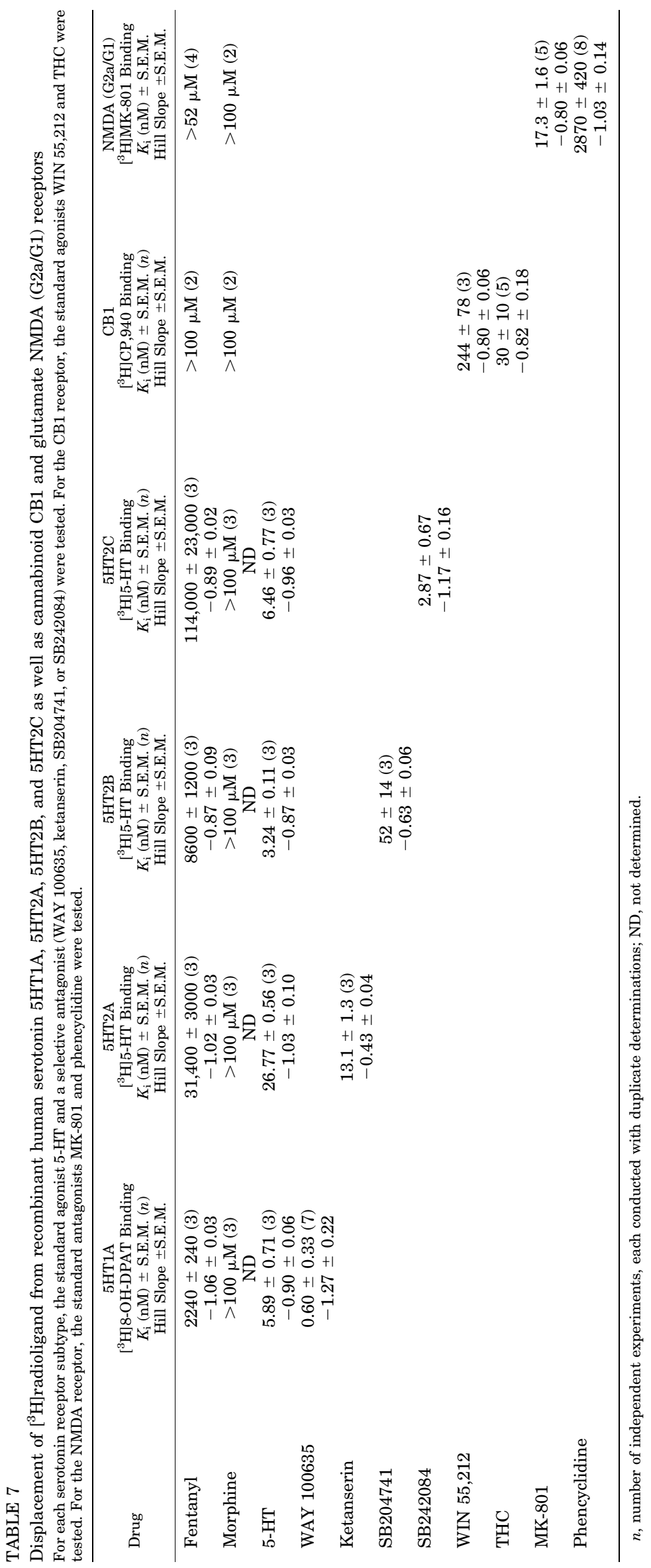



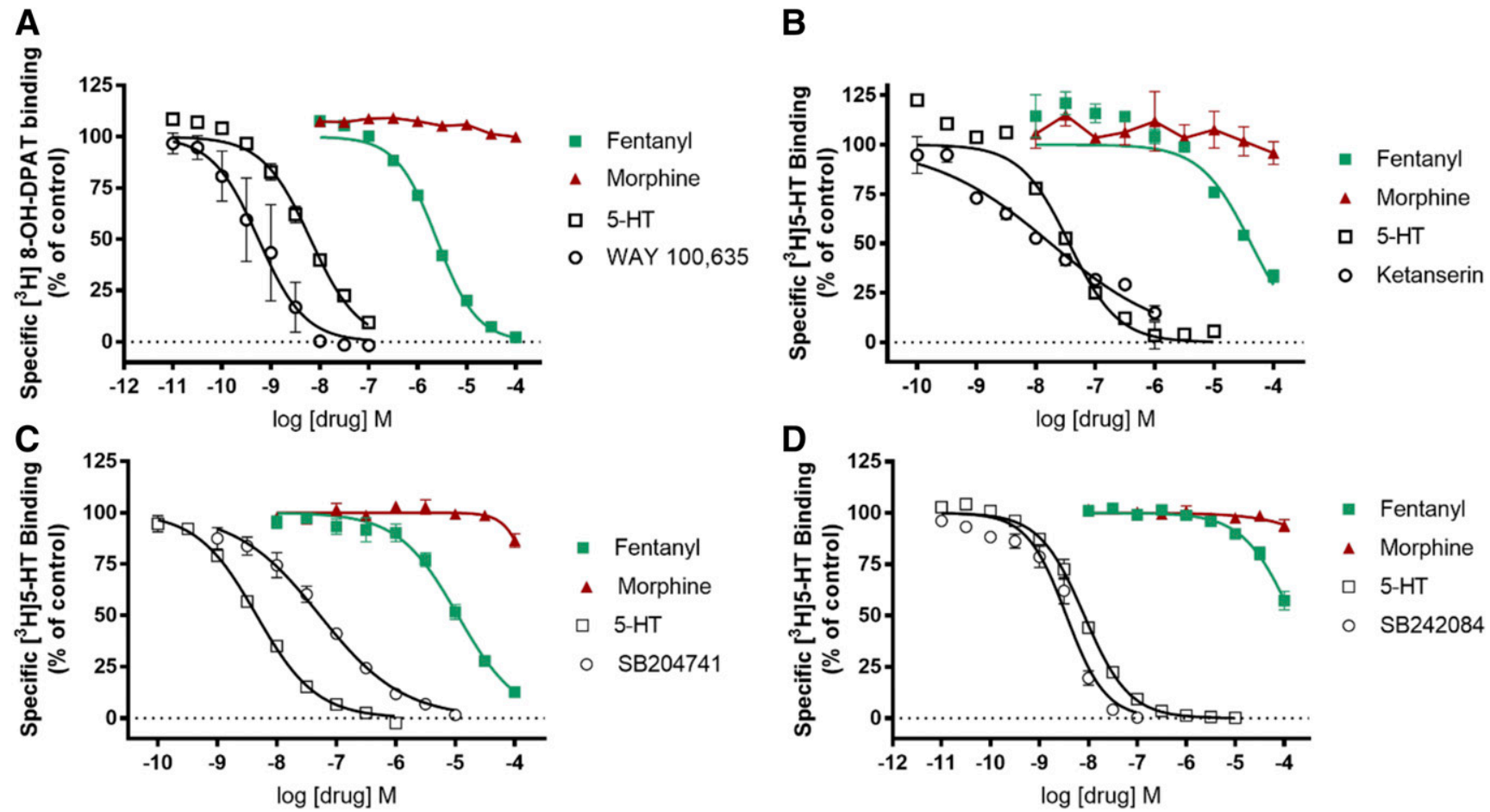

Fig. 8. Drug effects on radioligand binding to serotonin 5HT1A, 5HT2A, 5HT2B, and 5HT2C receptors. (A) 5HT1A receptor ([ $\left.\left.{ }^{3} \mathrm{H}\right] 8-\mathrm{OH}-\mathrm{DPAT}\right)$; (B) 5HT2A receptor $\left(\left[{ }^{3} \mathrm{H}\right] 5-\mathrm{HT}\right)$; (C) 5HT2B receptor $\left(\left[{ }^{3} \mathrm{H}\right] 5-\mathrm{HT}\right)$; and (D) 5HT2C receptor $\left(\left[{ }^{3} \mathrm{H}\right] 5-\mathrm{HT}\right)$. Data shown are the means \pm S.E.M. of three to seven experiments.

$\alpha_{1 \mathrm{D}}$-Adr (Table 3, $P<0.0001$ ), where norepinephrine had its greatest affinity by $\sim 10$ - to 20 -fold over $\alpha_{1 \mathrm{~A}}$-Adr and $\alpha_{1 \mathrm{~B}}$-Adr, respectively. The competitive binding pattern of F/FAs suggested by the compounds tested, if consistent among members of this class of drugs/opioids, may allow for the increased availability and coalescence of $\mathrm{NE}$ at $\alpha_{1 \mathrm{D}}-\mathrm{Adr}$ and offers an explanation for the consistency of the clinical effects seen with F/FAs. These differences in affinities and availability of norepinephrine (NE) for $\alpha_{1 \mathrm{D}}-\mathrm{Adr}$ binding could play an important role in the effects of $\mathrm{F} / \mathrm{FAs}$ on noradrenergic system function in the LC (primary noradrenergic system in mammalian central nervous system (CNS)) and cardiovascular system given the key distribution and variations in subtype dominance of $\alpha_{1}$-AdRs in these anatomic locations.

Epinephrine had higher affinity for $\alpha_{1 \mathrm{D}}$-Adr than fentanyl does $(P<0.001)$ and similar affinities as fentanyl at $\alpha_{1 \mathrm{~A}}-\mathrm{Adr}$ and $\alpha_{1 \mathrm{~B}}-\mathrm{Adr}(P>0.05)$. Phenylephrine had much lower affinity at $\alpha_{1 \mathrm{~A}}-\mathrm{Adr}$ and $\alpha_{1 \mathrm{~B}}-\mathrm{Adr}\left(P_{\mathrm{S}}<0.01\right)$ but similar affinity at $\alpha_{1 \mathrm{D}}$-Adr than fentanyl $(P>0.05)$, and these differences in affinity could affect response to agonist when fentanyl is present. It is noteworthy that carfentanil had greater affinity at the $\alpha_{1 \mathrm{~A}}$-Adr than epinephrine by nearly twofold. Prazosin and tamsulosin, receptor antagonists, had much higher affinity for $\left[{ }^{3} \mathrm{H}\right]$ prazosin binding at each receptor subtype than did fentanyl or carfentanil $\left(P_{\mathrm{S}}<0.001\right)$ and the Adr agonists (Table 3). However, prazosin had similar affinities for the subtypes, whereas tamsulosin affinities at the subtypes varied $\left(\alpha_{1 \mathrm{~A}}-\mathrm{Adr} \geq \alpha_{1 \mathrm{D}}-\mathrm{Adr}>>\alpha_{1 \mathrm{~B}}-\mathrm{Adr}, P<0.01\right)$, suggesting that each might be a useful tool for altering noradrenergic function affected by fentanyl, carfentanil, or other F/FAs.

In assays of receptor function, neither morphine, fentanyl, nor carfentanil had agonist activity at any $\alpha_{1}$-Adr subtype (Fig. 3; Table 3). The morphine $\mathrm{IC}_{50}$ value at blocking norepinephrine-stimulated IP-1 accumulation was greater than $100 \mu \mathrm{M}$ at each receptor subtype. Conversely, fentanyl was a relatively weak antagonist at $\alpha_{1 \mathrm{D}}-\mathrm{Adr}$ and inhibited 73\% of norepinephrine-mediated IP-1 accumulation. At $\alpha_{1 \mathrm{~A}} \mathrm{Adr}$ and $\alpha_{1 \mathrm{~B}}$-Adr, fentanyl blocked $100 \%$ of norepinephrinestimulated IP-1 accumulation and had higher potency compared with effects at $\alpha_{1 \mathrm{D}}$-Adr (Table $3, P<0.01$ ). Similarly, carfentanil was an antagonist with rank order of potency $\alpha_{1 \mathrm{~B}^{-}}$ Adr $>\alpha_{1 \mathrm{~A}}-\mathrm{Adr}>\alpha_{1 \mathrm{D}}-\mathrm{Adr}$. Norepinephrine and epinephrine had similar potencies $(P \mathrm{~S}>0.05)$ and full efficacy at each $\alpha_{1^{-}}$ Adr subtype, whereas phenylephrine had much lower potency than the neurotransmitters at each receptor subtype $(P \mathrm{~s}<$ 0.001 ) and was a partial agonist at $\alpha_{1 \mathrm{D}}$-Adr. Prazosin and tamsulosin completely blocked norepinephrine-stimulated IP-1 accumulation, with the same rank order of potencies $\left(\alpha_{1 \mathrm{D}}-\mathrm{Adr}>>\alpha_{1 \mathrm{~A}}-\mathrm{Adr}=\alpha_{1 \mathrm{~B}}-\mathrm{Adr}, \mathrm{Ps}<0.05\right)$ (Table 3$)$.

Fentanyl and Morphine Interactions with the VMAT2 and Neurotransmitter Transporters. Table 4 and Fig. 4, A-C indicate that fentanyl and carfentanil were very weak at displacing $\left[{ }^{125} \mathrm{I}\right] \mathrm{RTI}-55$ binding from the dopamine, serotonin, and norepinephrine transporters, with $K_{\mathrm{i}}$ values ranging from $>10$ to $69 \mu \mathrm{M}$. Morphine's affinity for the binding site at each transporter was even lower, with $K_{\mathrm{i}}$ values at or above $75 \mu \mathrm{M}$. Consistent with previous reports, cocaine displaced radioligand binding from the dopamine, serotonin, and norepinephrine transporters (Eshleman et al., 1999), with $K_{\mathrm{i}}$ values ranging from 404 to $1550 \mathrm{nM}$. Also consistent with previous reports, methamphetamine's $K_{\mathrm{i}}$ values ranged from $2.7 \mu \mathrm{M}$ at the $\left.{ }^{125} \mathrm{I}\right] \mathrm{RTI}-55$ binding site on the dopamine transporter to $117 \mu \mathrm{M}$ at the serotonin transporter. At the VMAT2, fentanyl had a $K_{\mathrm{i}}$ value for displacing $\left[{ }^{3} \mathrm{H}\right]$ dihydrotetrabenazine (DHTB) of $56 \mu \mathrm{M}$, and the carfentanil and morphine $K_{\mathrm{i}}$ values were over 10 and $100 \mu \mathrm{M}$, respectively 
(Fig. 4D; Table 3). Consistent with previous reports, methamphetamine, a VMAT2 substrate, was very weak at displacing $\left[{ }^{3} \mathrm{H}\right] \mathrm{DHTB}$ binding from the VMAT2, with a $K_{\mathrm{i}}$ value of $684 \mu \mathrm{M}$ (Eshleman et al., 2013). DHTB, included as a control for the assay, had a $K_{\mathrm{i}}$ of $74 \mathrm{nM}$.

Because drugs differ between their affinities for radioligand binding sites on transporters and their potencies at inhibiting transporter function, we examined $\left[{ }^{3} \mathrm{H}\right]$ neurotransmitter uptake by the respective recombinant human transporters and hVMAT2. The data in Table 4 and Fig. 5 indicate that $\mathrm{IC}_{50}$ values for morphine were greater than $100 \mu \mathrm{M}$, except at the serotonin transporter $(>83 \mu \mathrm{M})$. Fentanyl, however, had $\mathrm{IC}_{50}$ values ranging from $27.5 \mu \mathrm{M}$ at the norepinephrine transporter and $29.7 \mu \mathrm{M}$ at the dopamine transporter to $>85 \mu \mathrm{M}$ at the serotonin transporter. Carfentanil had an $\mathrm{IC}_{50}$ value of $4.46 \mu \mathrm{M}$ at the norepinephrine transporter. Importantly, and in contrast to morphine $\left(\mathrm{IC}_{50}>100 \mu \mathrm{M}\right)$, the fentanyl $\mathrm{IC}_{50}$ value for blocking $\left[{ }^{3} \mathrm{H}\right] 5$-HT uptake by the hVMAT2 was 911 nM (Fig. 5D), which is more potent than methamphetamine at blocking uptake ( $4 \mu \mathrm{M}, P<0.0001$, one-way ANOVA Dunnett's multiple comparisons) (Table 4 ). The $K_{\mathrm{i}} / \mathrm{IC}_{50}$ ratio suggests that both fentanyl (ratio 61) and methamphetamine (ratio 164) are binding to a site on the hVMAT2 that is more closely related to transporter function than is the $\left[{ }^{3} \mathrm{H}\right] \mathrm{DHTB}$ binding site (ratio 1.8) (Provencher et al., 2018). Carfentanil had an $\mathrm{IC}_{50}$ value of $4.1 \mu \mathrm{M}$ at the VMAT2.

Fentanyl and Morphine Interactions with Dopamine Receptor Subtypes. The data in Table 5 and Fig. 6 indicate that morphine, at concentrations up to $100 \mu \mathrm{M}$, did not displace radioligand binding from any dopamine receptor subtype. Fentanyl, however, had $K_{\mathrm{i}}$ values of $\sim 1$ and $\sim 1.7$ $\mu \mathrm{M}$ at the dopamine $\mathrm{D} 4.4\left[{ }^{3} \mathrm{H}\right]$ spiperone binding site and the dopamine D1 $\left[{ }^{3} \mathrm{H}\right] \mathrm{SCH} 23390$ binding site, respectively. At the $\left[{ }^{3} \mathrm{H}\right]$ spiperone binding sites on other D2-like receptors, fentanyl's $K_{\mathrm{i}}$ values were $\sim 15$ (D2) and $\sim 12 \mu \mathrm{M}$ (D3), indicating selectivity for the D4.4 receptor (Fig. 6D; Table 5). Dopamine receptor agonists (SKF38393, quinpirole) and antagonists (SCH23390, butaclamol, haloperidol) had $K_{\mathrm{i}}$ values for radioligand displacement resembling previously reported concentrations (Janowsky et al., 2014).

To determine whether fentanyl or morphine affects dopamine D1 or D4.4 function, we examined their ability to modulate adenylyl cyclase activity that is stimulated (D1) or blocked (D4.4) by these receptors, respectively. Table 6 and Fig. 7A indicate that neither fentanyl nor morphine stimulated adenylyl cyclase activity in C6-D1 cells. However, fentanyl, but not morphine, partially $(65.5 \%)$ inhibited the activity elicited by $100 \mathrm{nM}$ of dihydrexidine with an $\mathrm{IC}_{50}$ value of $27 \mu \mathrm{M}$, whereas SCH23390 completely blocked activation with an $\mathrm{IC}_{50}$ value of $3.9 \mathrm{nM}$ (Fig. 7B). In HEK-D4.4 cells, neither fentanyl nor morphine had agonist activity as measured by inhibition of forskolin-stimulated adenylyl cyclase activity (Fig. 7C). Fentanyl, not morphine, was a D4.4 antagonist, partially $(63 \%)$ blocking the quinpirole effect, with an $\mathrm{IC}_{50}$ value of $12.7 \mu \mathrm{M}$. Haloperidol completely blocked the quinpirole effect, with an $\mathrm{IC}_{50}$ value of $152 \mathrm{nM}$ (Fig. 7D; Table 6).

Fentanyl and Morphine Interactions with Serotonin Receptor Subtypes. Table 7 and Fig. 8 indicate the affinities of fentanyl and morphine at the $\left[{ }^{3} \mathrm{H}\right] 8-\mathrm{OH}-\mathrm{DPAT}$ binding site on the recombinant h5-HT1A receptor and at $\left[{ }^{3} \mathrm{H}\right] 5-\mathrm{HT}$ binding sites on the recombinant h5-HT2A, $2 \mathrm{~B}$, and $2 \mathrm{C}$ receptors. In all cases, morphine $K_{\mathrm{i}}$ values were over $100 \mu \mathrm{M}$. However, fentanyl $K_{\mathrm{i}}$ values ranged from $\sim 2.2 \mu \mathrm{M}$ at the 5 -HT1A receptor to $114 \mu \mathrm{M}$ at the 5 -HT2C receptor. Other drugs, selective for the respective receptor subtypes, had effects resembling previously reported $K_{\mathrm{i}}$ values (Eshleman et al., 2013).

Fentanyl and Morphine Interactions with the Recombinant Human CB1 Cannabinoid and NMDA (G2a/G1) Receptors. Table 7 indicates that neither fentanyl nor morphine displaced $\left[{ }^{3} \mathrm{H}\right] \mathrm{CP} 55,940$ binding to the recombinant hCB1 cannabinoid receptor $\left(K_{\mathrm{i}}>100 \mu \mathrm{M}\right)$ or $\left[{ }^{3} \mathrm{H}\right] \mathrm{MK}-801$ binding to the recombinant hNMDA (G2a/G1) receptor. Selective agents included in the assays for comparison had $K_{\mathrm{i}}$ values resembling previously reported values (Bresink et al., 1995; Pertwee, 2008a,b).

\section{Discussion}

The hypothesis that deaths caused by exposure to F/FAs are not mediated by MORs is based on the following: 1) naloxone availability has not significantly reduced F/FA-related deaths (Baumann et al., 2018); 2) fentanyl metabolites are almost nonexistent in tissue from patients who died of fentanyl overdose, suggesting rapid cardiopulmonary collapse that contrasts with the effects of heroin (Burns et al., 2016); 3) public health data from death scenes and eyewitness reports of F/FA-related deaths show consistent evidence of rapid and atypical death compared with heroin overdose (Somerville et al., 2017); 4) published data on drug effects in animal models and radioligand binding data indicate that fentanyl causes the rapid onset of severe muscle rigidity via cerulospinal fibers innervated/controlled by $\alpha_{1}$-Adr postsynaptic receptors (Lui et al., 1989, 1990; Tsou et al., 1989; Fu et al., 1997); 5) the principal effect of high-dose F/FAs is rapid closure of vocal cords followed by rigidity of the chest wall (Scamman, 1983; Bennett et al., 1997); 6) fentanyl isolates the vagal medullary fibers that innervate the vocal cords, contributing to vocal cord closure (Lalley, 2003); and 7) activation of $\alpha_{1}$-Adr subtypes facilitates excitatory inputs to medullary airway vagal preganglionic neurons that modulate laryngeal and tracheal musculature (Haxhiu et al., 2003; Ge et al., 2015).

Experimental results herein, comparing the effects of morphine, naloxone, norepinephrine, fentanyl, and carfentanil in the same assay, indicate that pharmacologies differ and that fentanyl binds to $\alpha_{1}$-Adrs, add new data on carfentanil- $\alpha_{1}$ Adr subtype binding, and indicate that the similar selectivity of fentanyl analogs to $\alpha_{1}$-Adr subtypes as a possible underlying mechanism in the lethality of this synthetic opioid family. $\alpha_{1}$-Adr subtypes have differing anatomic distributions that further implicate their role in the effects of fentanyl but not morphine. For example, the $\alpha_{1 \mathrm{D}}-\mathrm{Adr}$, but not $\alpha_{1 \mathrm{~A}}$-Adr or $\alpha_{1 \mathrm{~B}}$-Adr subtypes, found predominantly in the large coronary arteries, mediates vasoconstriction (Jensen et al., 2009). The $\alpha_{1 \mathrm{~B}} \mathrm{Adr}$, found in pulmonary arteries, mediates contraction (Sohn et al., 2005). Norepinephrine had the highest affinity for $\alpha_{1 \mathrm{D}}$-Adr compared with $\alpha_{1 \mathrm{~A}}$-Adr and $\alpha_{1 \mathrm{~B}}$-Adr (Table 3). A large and rapid fentanyl-induced norepinephrine release (Hicks et al., 1981) should cause $\alpha_{1 \mathrm{D}}$-Adr-mediated contraction of coronary arteries, negatively impacting cardiovascular function (Ray et al., 2016). Interestingly, fentanyl was a very weak antagonist at $\alpha_{1 \mathrm{D}}$-Adr compared with its ability to antagonize norepinephrine-mediated IP-1 formation at $\alpha_{1 \mathrm{~A}}-\mathrm{Adr}$ and 
$\alpha_{1 \mathrm{~B}}$-Adr (Table 3 ), suggesting a possible focusing of norepinephrine effects on the $\alpha_{1 \mathrm{D}}$-Adr subtype when fentanyl is present.

Additionally, fentanyl and carfentanil, but not morphine, blocked VMAT2-mediated neurotransmitter uptake $\left(\mathrm{IC}_{50}\right.$ $\sim 911 \mathrm{nM}$ ) but was much weaker at blocking radioligand binding (Table 4). Lobeline, a VMAT2 uptake blocker, has some structural similarities to fentanyl, and fentanyl is more potent than lobeline at blocking VMAT2-mediated $\left[{ }^{3} \mathrm{H}\right]$ neurotransmitter uptake (lobeline $\mathrm{IC}_{50}=4.2 \mu \mathrm{M}$ ) (Provencher et al., 2018). Differing $\mathrm{IC}_{50}$ values for uptake and $K_{\mathrm{i}}$ values for binding are consistent with the effects of transporter substrates (Cozzi et al., 2009). The VMAT2 transports neurotransmitter into synaptic vesicles (Erickson et al., 1996); however, preliminary data indicated that the VMAT2 did not transport $\left[{ }^{3} \mathrm{H}\right]$ fentanyl (data not shown). Thus, fentanyl appears to block uptake but not to displace neurotransmitter from the transporter/vesicle. The resulting increase in intracellular norepinephrine availability and norepinephrine synaptic release via the presynaptic transporter, coupled with fentanyl blockade of $\alpha_{1 \mathrm{~A}^{-}}$and $\alpha_{1 \mathrm{~B}}$-Adr (the $\alpha_{1 \mathrm{D}^{-}} \mathrm{Adr}$ has relatively lower affinity for fentanyl), could result in more selective $\alpha_{1 \mathrm{D}}$-Adr stimulation, consistent with deleterious $\alpha_{1 \mathrm{D}^{-}}$ mediated consequences, including coronary artery vasospasm, as mentioned above.

Dopamine receptors had differential affinity for fentanyl, with the D1 and D4.4 receptors having the highest affinity, $\sim 1$ $\mu \mathrm{M}$ (Table 5), and fentanyl was a weak antagonist at both receptors (Table 6). In agreement with previous reports, fentanyl's potency at blocking D1 receptor-mediated cAMP accumulation (Govoni et al., 1975) was similar to fentanyl's affinity at blocking $\left[{ }^{3} \mathrm{H}\right] \mathrm{SCH} 23390$ binding to the $\mathrm{D} 1$ receptor. Lalley $(2005 a, b)$ suggested that dopamine D1 receptor agonists might reverse opioid-induced respiratory depression but not antinociception, whereas antagonists enhance respiratory depression. Therefore, fentanyl-mediated blockade of the D1 receptor subtypes should increase MOR-mediated respiratory depression, necessitating increased administration of naloxone, consistent with findings related to fentanyl overdose.

Previous reports also used $\left[{ }^{3} \mathrm{H}\right] 8-\mathrm{OH}-\mathrm{DPAT}$ to characterize fentanyl's effects at 5HT1A receptors and obtained almost identical results $\left(K_{\mathrm{i}} \sim 2 \mu \mathrm{M}\right)$ (Rickli et al., 2018). However, we report that fentanyl had micromolar affinity $(31 \mu \mathrm{M})$ at the $5 \mathrm{HT} 2 \mathrm{~A}$ receptor as measured by using an agonist, $\left[{ }^{3} \mathrm{H}\right] 5$-HT, whereas Rickli et al. (2018) obtained a $K_{\mathrm{i}}$ value of $1.3 \mu \mathrm{M}$ by using the antagonist $\left[{ }^{3} \mathrm{H}\right]$ ketanserin. Differences in affinity for the binding sites could be because of the use of agonist versus antagonist ligand. We found no reports indicating direct effects of fentanyl on receptor function that could corroborate any differences in affinity caused by differences in radioligand. Fentanyl had very low affinity for the 5HT2C receptor, regardless of radioligand, and our data (Table 7) are the first indication of low affinity of fentanyl at the recombinant human 5HT2B receptor.

In agreement with a previous report (Fernández-Fernández et al., 2014) indicating that fentanyl did not displace $\left[{ }^{3} \mathrm{H}\right]$ CP55,940 binding from CB1 receptors in human cortical preparations, neither fentanyl nor morphine displaced $\left[{ }^{3} \mathrm{H}\right]$ CP55,940 binding from the recombinant human receptor (Table 7). Additionally, neither fentanyl nor morphine blocked $\left[{ }^{3} \mathrm{H}\right] \mathrm{MK}-801$ binding to recombinant NMDA receptors (G2a/G1), in agreement with a report describing a rat cortical wedge preparation (Ebert et al., 1998). The low affinity precluded functional tests, but both fentanyl and morphine, at high micromolar concentrations, block the function of NMDA channels of various subunit compositions expressed in Xenopus oocytes (Yamakura et al., 1999).

Whether the $K_{\mathrm{i}}$ and $\mathrm{IC}_{50}$ values described above are relevant to the symptoms of fentanyl overdose depend on pharmacokinetic assumptions. Fentanyl is lipophilic, and calculated brain lipid concentrations can reach almost $3 \mathrm{mM}$ (Stone and DiFazio, 1988). The high octanol/water partition coefficient for fentanyl (9550) and carfentanil $(\sim>13,000)$ suggests that toxic brain interstitial concentrations in the high nanomolars to low micromolars range are relevant (Stone and DiFazio, 1988). However, calculations based on plasma drug concentrations suggest that brain concentrations are much lower (Kalvass et al., 2007; Heiskanen et al., 2015). Sheep models have demonstrated significant first pass peak concentrations reaching the brain after intravenous drug administration that may be up to 4000-times greater than plasma concentrations within the first minute of circulation (Upton, 1996). The pharmacokinetic assumptions that illicit fentanyl administration results in very high (millimolars) concentrations in various compartments suggest that our data (low micromolars $K_{\mathrm{i}}$ and $\mathrm{IC}_{50}$ values) at various receptors and transporters are pharmacologically relevant and contribute to the differences between morphine and fentanyl in clinical symptoms and outcomes.

The relevance of these findings is significant given the incidence of deaths from F/FAs. High doses of F/FAs in animal models increase signal output from the LC, causing severe and sustained chest wall rigidity and are mediated by the direct interaction of noradrenaline and $\alpha_{1}$-Adr receptors (Lui et al., 1989). Similarly, LC output controls medullary vagal motor fibers innervating the airway, whereas fentanyl selectively activates vagal motor fibers (Haxhiu et al., 2003; Lalley, 2003). These reports and our data support plausible mechanisms for increased noradrenergic activity and selective non-MOR receptor/VMAT2 transporter blockade that is the prerequisite for synthetic opioid-induced overdose, with resulting laryngospasm, cardiovascular, and secondary hepatic compromise (Yasuda et al., 1978; Scamman, 1983; Lui et al., 1989, 1990, 1993, 1995; Bennett et al., 1997; Burns et al., 2016; Somerville et al., 2017; Torralva and Janowsky, 2019). These mechanisms appear to be distinct from the effects of F/FAs at MORs (Sokoll et al., 1972).

F/FAs increase norepinephrine in peripheral circulation (Thomson et al., 1988). However, F/FAs, and in fact all opioids, decrease norepinephrine release in the CNS (Aghajanian, 1982). Our new data demonstrate two mechanisms by which fentanyl may alter norepinephrine disposition: 1) fentanyl blocked intracellular vesicular reuptake of neurotransmitter (Fig. 5), increasing their cytoplasmic concentrations; and 2) fentanyl selectively blocked $\alpha_{1}$-Adr receptor subtypes (Table 3 ) in a manner that isolates and focuses noradrenergic activity on the $\alpha_{1 \mathrm{D}}-\mathrm{Adr}$ subtype (Fig. 3), where norepinephrine has its highest affinity.

Our hypothesis concerning a nonopioid fentanyl-modulated pathway has relevance for the current fentanyl-driven opioid crisis, in which the increased deaths and reduced sensitivity to naloxone may be because of acute vocal cord closure and cardiovascular dysfunction mediated by noradrenergic activity at $\alpha_{1 \mathrm{D}}$-Adr receptors, where opioid antagonists would have little effect (Willette and Sapru, 1982; Torralva and Janowsky, 2019). These data suggest the underlying mechanisms for FIRE and indicate new directions for development of 
supplementary modes of emergency treatment and strategic interventional targets (e.g., $\alpha_{1}$-Adr receptor subtypes) that may improve survival from F/FA exposure.

In conclusion, the current novel data may be relevant to the development of therapeutics targeting the underlying mechanism of the adverse effects and deaths associated with F/FAs. The affinity and effects of fentanyl at $\alpha_{1}$-Adr subtypes and the VMAT2 differ significantly from morphine. Thus, profiling of new fentanyl analogs and synthetic opioids against the receptor panel described here could help to identify therapeutic candidates with fewer adverse clinical effects and indicate strategic intervention points for the lethal mechanisms of these compounds.

\section{Authorship Contributions}

Participated in research design: Torralva, Eshleman, Schutzer, Janowsky.

Conducted experiments: Eshleman, Swanson, Schmachtenberg, Bloom, Wolfrum, Reed.

Performed data analysis: Eshleman, Swanson, Schmachtenberg, Schutzer, Bloom, Wolfrum, Reed, Janowsky.

Wrote or contributed to the writing of the manuscript: Torralva, Eshleman, Swanson, Schmachtenberg, Schutzer, Bloom, Wolfrum, Reed, Janowsky.

\section{References}

Aghajanian GK (1982) Central noradrenergic neurons: a locus for the functional interplay between alpha-2 adrenoceptors and opiate receptors. J Clin Psychiatry 43:20-24.

Baumann MH, Kopajtic TA, and Madras BK (2018) Pharmacological research as a key component in mitigating the opioid overdose crisis. Trends Pharmacol Sci 39: 995-998.

Bennett JA, Abrams JT, Van Riper DF, and Horrow JC (1997) Difficult or impossible ventilation after sufentanil-induced anesthesia is caused primarily by vocal cord closure. Anesthesiology 87:1070-1074

Bergström KA, Jolkkonen J, Kuikka JT, Akerman KK, Viinamäki H, Airaksinen O, Länsimies E, and Tiihonen J (1998) Fentanyl decreases beta-CIT binding to the dopamine transporter. Synapse 29:413-415.

Bresink I, Danysz W, Parsons CG, and Mutschler E (1995) Different binding affinities of NMDA receptor channel blockers in various brain regions--indication of NMDA receptor heterogeneity. Neuropharmacology 34:533-540.

Burns G, DeRienz RT, Baker DD, Casavant M, and Spiller HA (2016) Could chest wall rigidity be a factor in rapid death from illicit fentanyl abuse? Clin Toxico (Phila) 54:420-423.

Cheng Y and Prusoff WH (1973) Relationship between the inhibition constant (K1) and the concentration of inhibitor which causes 50 per cent inhibition (I50) of an enzymatic reaction. Biochem Pharmacol 22:3099-3108.

Chesser R, Pardi J, Concheiro M, and Cooper G (2019) Distribution of synthetic opioids in postmortem blood, vitreous humor and brain. Forensic Sci Int $\mathbf{3 0 5}$ 109999.

Cozzi NV, Gopalakrishnan A, Anderson LL, Feih JT, Shulgin AT, Daley PF, and Ruoho AE (2009) Dimethyltryptamine and other hallucinogenic tryptamines exhibit substrate behavior at the serotonin uptake transporter and the vesicle monoamine transporter. J Neural Transm (Vienna) 116:1591-1599.

de Waal PW, Shi J, You E, Wang X, Melcher K, Jiang Y, Xu HE, and Dickson BM (2020) Molecular mechanisms of fentanyl mediated $\beta$-arrestin biased signaling. PLOS Comput Biol 16:e1007394.

Ebert B, Andersen S, Hjeds H, and Dickenson AH (1998) Dextropropoxyphene acts as a noncompetitive N-methyl-D-aspartate antagonist. J Pain Symptom Manage 15 $269-274$

Erickson JD, Schafer MK, Bonner TI, Eiden LE, and Weihe E (1996) Distinct pharmacological properties and distribution in neurons and endocrine cells of two isoforms of the human vesicular monoamine transporter. Proc Natl Acad Sci USA 93:5166-5171.

Eshleman AJ, Carmolli M, Cumbay M, Martens CR, Neve KA, and Janowsky A (1999) Characteristics of drug interactions with recombinant biogenic amine transporters expressed in the same cell type. J Pharmacol Exp Ther 289:877-885. Eshleman AJ, Wolfrum KM, Hatfield MG, Johnson RA, Murphy KV, and Janowsky A (2013) Substituted methcathinones differ in transporter and receptor interactions. Biochem Pharmacol 85:1803-1815.

Eshleman AJ, Wolfrum KM, Reed JF, Kim SO, Johnson RA, and Janowsky A (2018) Neurochemical pharmacology of psychoactive substituted N-benzylphenethylamines: high potency agonists at 5- $\mathrm{HT}_{2 \mathrm{~A}}$ receptors. Biochem Pharmacol 158:27-34

Farrens DL, Dunham TD, Fay JF, Dews IC, Caldwell J, and Nauert B (2002) Design, expression, and characterization of a synthetic human cannabinoid receptor and cannabinoid receptor/ G-protein fusion protein. J Pept Res 60:336-347.

Fernández-Fernández C, Callado LF, Girón R, Sánchez E, Erdozain AM, LópezMoreno JA, Morales P, Rodríguez de Fonseca F, Fernández-Ruiz J, Goya P, et al (2014) Combining rimonabant and fentanyl in a single entity: preparation and pharmacological results. Drug Des Devel Ther 8:263-277.
Fu MJ, Tsen LY, Lee TY, Lui PW, and Chan SH (1997) Involvement of cerulospinal glutamatergic neurotransmission in fentanyl-induced muscular rigidity in the rat. Anesthesiology 87:1450-1459.

Ge D, Yan X, Guo Y, Chen X, Guan R, Chen Y, Qiu D, and Wang J (2015) Activation of alpha1-adrenoceptors facilitates excitatory inputs to medullary airway vagal preganglionic neurons. J Appl Physiol (1985) 119:686-695.

Govoni S, Kumakura K, Spano PF, Tonon GC, and Trabucchi M (1975) Interaction of narcotic analgesics with dopamine receptors in rat brain. Pharmacol Res Commun 7:95-100.

Grant ER, Bacskai BJ, Pleasure DE, Pritchett DB, Gallagher MJ, Kendrick SJ, Kricka LJ, and Lynch DR (1997) N-methyl-D-aspartate receptors expressed in a nonneuronal cell line mediate subunit-specific increases in free intracellular calcium. J Biol Chem 272:647-656.

Grell FL, Koons RA, and Denson JS (1970) Fentanyl in anesthesia: a report of 500 cases. Anesth Analg 49:523-532.

Haxhiu MA, Kc P, Neziri B, Yamamoto BK, Ferguson DG, and Massari VJ (2003) Catecholaminergic microcircuitry controlling the output of airway-related vagal preganglionic neurons. J Appl Physiol (1985) 94:1999-2009.

Hedegaard H, Bastian BA, Tinidad JP, Spencer M, and Warner M (2018) Drugs most frequently involved in drug overdose deaths: United States, 2011-2016, Natl Vital Stat Rep 67, pp 1-14

Heiskanen T, Langel K, Gunnar T, Lillsunde P, and Kalso EA (2015) Opioid concentrations in oral fluid and plasma in cancer patients with pain. J Pain Symptom Manage 50:524-532.

Hicks HC, Mowbray AG, and Yhap EO (1981) Cardiovascular effects of and catecholamine responses to high dose fentanyl-O2 for induction of anesthesia in patients with ischemic coronary artery disease. Anesth Analg 60:563-568.

Hustveit O (1994) Binding of fentanyl and pethidine to muscarinic receptors in rat brain. Jpn J Pharmacol 64:57-59.

Jannetto PJ, Helander A, Garg U, Janis GC, Goldberger B, and Ketha H (2019) The fentanyl epidemic and evolution of fentanyl analogs in the United States and the European union. Clin Chem 65:242-253.

Janowsky A, Eshleman AJ, Johnson RA, Wolfrum KM, Hinrichs DJ, Yang J, Zabriskie TM, Smilkstein MJ, and Riscoe MK (2014) Mefloquine and psychotomimetics share neurotransmitter receptor and transporter interactions in vitro. Psychopharmacology (Berl) 231:2771-2783.

Jensen BC, Swigart PM, Laden ME, DeMarco T, Hoopes C, and Simpson PC (2009) The alpha-1D Is the predominant alpha-1-adrenergic receptor subtype in human epicardial coronary arteries. J Am Coll Cardiol 54:1137-1145.

Jiwa N, Sheth H, and Silverman R (2018) Naloxone-induced non-cardiogenic pulmonary edema: a case report. Drug Saf Case Rep 5:20.

Kalvass JC, Olson ER, Cassidy MP, Selley DE, and Pollack GM (2007) Pharmacokinetics and pharmacodynamics of seven opioids in P-glycoprotein-competent mice: assessment of unbound brain EC50, $\mathrm{u}$ and correlation of in vitro, preclinical, and clinical data. J Pharmacol Exp Ther 323:346-355.

Katchman AN, McGroary KA, Kilborn MJ, Kornick CA, Manfredi PL, Woosley RL, and Ebert SN (2002) Influence of opioid agonists on cardiac human ether-a-go-gorelated gene $\mathrm{K}(+)$ currents. J Pharmacol Exp Ther 303:688-694.

Lalley PM (2003) Mu-opioid receptor agonist effects on medullary respiratory neurons in the cat: evidence for involvement in certain types of ventilatory disturbances. Am J Physiol Regul Integr Comp Physiol 285:R1287-R1304.

Lalley PM (2005a) D1-dopamine receptor agonists prevent and reverse opiate depression of breathing but not antinociception in the cat. Am J Physiol Regul Integr Comp Physiol 289:R45-R51.

Lalley PM (2005b) D1-dopamine receptor blockade slows respiratory rhythm and enhances opioid-mediated depression. Respir Physiol Neurobiol 145:13-22.

Lui PW, Chang GJ, Lee TY, and Chan SH (1993) Antagonization of fentanyl-induced muscular rigidity by denervation of the coerulospinal noradrenergic pathway in the rat. Neurosci Lett 157:145-148.

Lui PW, Lee TY, and Chan SH (1989) Involvement of locus coeruleus and noradrenergic neurotransmission in fentanyl-induced muscular rigidity in the rat Neurosci Lett 96:114-119.

Lui PW, Lee TY, and Chan SH (1990) Involvement of coerulospinal noradrenergic pathway in fentanyl-induced muscular rigidity in rats. Neurosci Lett 108: $183-188$

Lui PW, Tsen LY, Fu MJ, Yeh CP, Lee TY, and Chan SH (1995) Inhibition by intrathecal prazosin but not yohimbine of fentanyl-induced muscular rigidity in the rat. Neurosci Lett 201:167-170.

Martin DC, Introna RP, and Aronstam RS (1991) Fentanyl and sufentanil inhibit agonist binding to 5 -HT1A receptors in membranes from the rat brain. Neuropharmacology 30:323-327.

McClain DA and Hug CC Jr. (1980) Intravenous fentanyl kinetics. Clin Pharmacol Ther 28:106-114.

Peng PW and Sandler AN (1999) A review of the use of fentanyl analgesia in the management of acute pain in adults. Anesthesiology 90:576-599.

Pertwee RG (2008a) The diverse CB1 and CB2 receptor pharmacology of three plant cannabinoids: delta9-tetrahydrocannabinol, cannabidiol and delta9tetrahydrocannabivarin. Br J Pharmacol 153:199-215.

Pertwee RG (2008b) Ligands that target cannabinoid receptors in the brain: from THC to anandamide and beyond. Addict Biol 13:147-159.

Provencher BA, Eshleman AJ, Johnson RA, Shi X, Kryatova O, Nelson J, Tian J, Gonzalez M, Meltzer PC, and Janowsky A (2018) Synthesis and discovery of arylpiperidinylquinazolines: new inhibitors of the vesicular monoamine transporter. J Med Chem 61:9121-9131.

Ray WA, Chung CP, Murray KT, Hall K, and Stein CM (2016) Prescription of longacting opioids and mortality in patients with chronic noncancer pain. JAMA 315: 2415-2423

Rickli A, Liakoni E, Hoener MC, and Liechti ME (2018) Opioid-induced inhibition of the human 5-HT and noradrenaline transporters in vitro: link to clinical reports of serotonin syndrome. Br J Pharmacol 175:532-543. 
Scamman FL (1983) Fentanyl-O2-N2O rigidity and pulmonary compliance. Anesth Analg 62:332-334.

Shi X, Walter NA, Harkness JH, Neve KA, Williams RW, Lu L, Belknap JK, Eshleman AJ, Phillips TJ, and Janowsky A (2016) Genetic polymorphisms affect mouse and human trace amine-associated receptor 1 function. PLoS One 11:e0152581.

Slavova S, Costich JF, Bunn TL, Luu H, Singleton M, Hargrove SL, Triplett JS, Quesinberry D, Ralston W, and Ingram V (2017) Heroin and fentanyl overdoses in Kentucky: epidemiology and surveillance. Int J Drug Policy 46:120-129.

Sohn JT, Ding X, McCune DF, Perez DM, and Murray PA (2005) Fentanyl attenuates alpha1B-adrenoceptor-mediated pulmonary artery contraction. Anesthesiology 103:327-334.

Sokoll MD, Hoyt JL, and Gergis SD (1972) Studies in muscle rigidity, nitrous oxide, and narcotic analgesic agents. Anesth Analg 51:16-20.

Somerville NJ, O’Donnell J, Gladden RM, Zibbell JE, Green TC, Younkin M, Ruiz S Babakhanlou-Chase H, Chan M, Callis BP, et al. (2017) Characteristics of fentanyl overdose - Massachusetts, 2014-2016. MMWR Morb Mortal Wkly Rep 66:382-386 Stanley TH (2014) The fentanyl story. J Pain 15:1215-1226.

Stone DJ and DiFazio CA (1988) Anesthetic action of opiates: correlations of lipid solubility and spectral edge. Anesth Analg 67:663-666.

Streisand JB, Bailey PL, LeMaire L, Ashburn MA, Tarver SD, Varvel J, and Stanley TH (1993) Fentanyl-induced rigidity and unconsciousness in human volunteers. Incidence, duration, and plasma concentrations. Anesthesiology 78:629-634.

Thomson IR, Hudson RJ, Rosenbloom M, and Torchia MG (1988) Catecholamine responses to anesthetic induction with fentanyl and sufentanil. J Cardiothorac Anesth 2:18-22.

Torralva R and Janowsky A (2019) Noradrenergic mechanisms in fentanyl-mediated rapid death explain failure of naloxone in the opioid crisis. J Pharmacol Exp Ther 371:453-475.

Traynor JR and Nahorski SR (1995) Modulation by mu-opioid agonists of guanosine$5^{\prime}$-O-(3-[35S]thio)triphosphate binding to membranes from human neuroblastoma SH-SY5Y cells. Mol Pharmacol 47:848-854
Tschirhart JN, Li W, Guo J, and Zhang S (2019) Blockade of the human ether A-gogo-related gene (hERG) potassium channel by fentanyl. Mol Pharmacol 95: 386-397.

Tsou MY, Lui PW, Lee TY, Pan JT, and Chan SH (1989) Differential effects of prazosin and yohimbine on fentanyl-induced muscular rigidity in rats. Neuropharmacology 28:1163-1168.

Upton RN (1996) A model of the first pass passage of drugs from i.v. injection site to the heart--parameter estimates for lignocaine in the sheep. $\mathrm{Br} J$ Anaesth 77: $764-772$

Vasudevan L, Vandeputte M, Deventer M, Wouters E, Cannaert A, and Stove CP (2020) Assessment of structure-activity relationships and biased agonism at the $\mathrm{Mu}$ opioid receptor of novel synthetic opioids using a novel, stable bio-assay platform. Biochem Pharmacol 177:113910.

Willette RN and Sapru HN (1982) Pulmonary opiate receptor activation evokes a cardiorespiratory reflex. Eur J Pharmacol 78:61-70.

Yamakura T, Sakimura K, and Shimoji K (1999) Direct inhibition of the N-methyl-Daspartate receptor channel by high concentrations of opioids. Anesthesiology 91: $1053-1063$

Yamanoue T, Brum JM, Estafanous FG, Khairallah PA, and Ferrario CM (1993) Fentanyl attenuates porcine coronary arterial contraction through M3-muscarinic antagonism. Anesth Analg 76:382-390.

Yang M, Reese J, Cotecchia S, and Michel MC (1998) Murine alpha1-adrenoceptor subtypes. I. Radioligand binding studies. J Pharmacol Exp Ther 286:841-847.

Yasuda I, Hirano T, Yusa T, and Satoh M (1978) Tracheal constriction by morphine and by fentanyl in man. Anesthesiology 49:117-119.

Address correspondence to: Aaron Janowsky, Research Service (R\&D22), VA Portland Health Care System, 3710 S.W. U.S. Veterans Hospital Rd. Portland OR 97239. E-mail: janowsky@ohsu.edu 